\title{
Hanford Site Ground-Water \\ Model: Geographic Information System Linkages and Model Enhancements, FY 1993
}

\author{
S. K. Wurstner \\ J. L. Devary
}

December 1993

Prepared for

the U.S. Department of Energy

under Contract DE-ACO6-76RLO 1830

Pacific Northwest Laboratory

Richland, Washington 99352

\section{MASTER}




\section{Executive Summary}

Models of the unconfined aquifer are important tools that are used to 1) identify and quantify existing, emerging, or potential ground-water quality problems, 2) predict changes in ground-water flow and contaminant transport as waste-water discharge operations change, and 3) assess the potential for contaminants to migrate from the U. S. Department of Energy's Hanford Site through the ground water. Formerly, most of the numerical models developed at the Hanford Site were two-dimensional. However, contaminant concentrations cannot be accurately predicted with a two-dimensional model, which assumes a constant vertical distribution of contaminants in the aquifer. Development of two- and three-dimensional models of ground-water flow based on the Coupled Fluid, Energy, and Solute Transport (CFEST) code began in the mid-1980s. The CFEST code was selected because of its ability to simulate both ground-water flow and contaminant transport. Physical processes that can be modeled by CFEST include aquifer geometry, heterogeneity, boundary conditions, and initial conditions.

The CFEST ground-water modeling library has been integrated with the commercially available geographic information system (GIS) ARC/INFO. The display and analysis capabilities of a GIS are well suited to the size and diversity of databases being generated at the Hanford Site. The ability to visually inspect large databases through a graphical analysis tool provides a stable foundation for site assessments and ground-water modeling studies.

Any ground-water flow model being used by an ongoing project should be continually updated and refined to reflect the most current knowledge of the system. The two-dimensional ground-water flow model being used in support of the Ground-Water Surveillance Project has recently been updated and enhanced. One major enhancement was the extension of the model area to include North Richland. In addition, the model was converted to the Lambert metric coordinate system and units were converted to meters to provide easier comparison of modeled results to measured values. This conversion, done in 1993, made the model more compatible with existing Hanford basemaps as well as other Site activities.

A three-dimensional, multilayer ground-water model is being developed based on the threedimensional geohydrologic conceptual model being developed for the Ground-Water Surveillance Project. The transmissivity distribution and boundary conditions are taken from the current twodimensional ground-water model. Future work will include re-evaluating the boundary conditions 
of the model (in particular, the Columbia River elevations), surface recharge, and, potentially, discharges from the underlying basalt formation to the unconfined aquifer unit.

To develop the three-dimensional, multilayer ground-water model, the current twodimensional model was converted to a single-layer, three-dimensional flow model using the underlying basalt formation as the base of the model. The December 1979 water-table elevation and the most current top-of-basalt surface were used to define the single-layer, unconfined aquifer unit of the new three-dimensional model.

Hydraulic conductivities for the three-dimensional model were derived from the transmissivity distribution of the two-dimensional model. All boundary conditions from the twodimensional model were retained in the three-dimensional, single-layer model. Steady-state flow simulations (based on 1979 discharge conditions) showed good agreement between the predicted water tables of the two-dimensional model and the three-dimensional, single-layer model. Contour maps of the predicted head at the top-of-basalt, representing the base of the model, were essentially identical to the predicted results at the water table. Travel path analyses also showed very good agreement between the two- and three-dimensional results, with the only difference being that several travel paths terminated upon encountering a boundary at the top or base of the model.

This report summarizes the existing two-dimensional model used by the Ground-Water Surveillance Project for simulations at the Hanford Site and reports on the status of the new, threedimensional model being developed. 


\section{Contents}

Executive Summary $\ldots \ldots \ldots \ldots \ldots \ldots \ldots \ldots \ldots \ldots \ldots \ldots \ldots \ldots \ldots \ldots$ iii

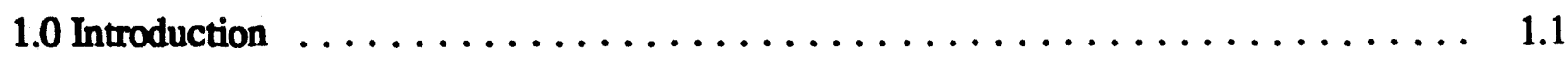

1.1 History of Previous Modeling Efforts $\ldots \ldots \ldots \ldots \ldots \ldots \ldots \ldots \ldots, 1.1$

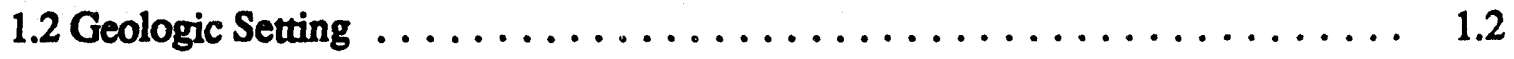

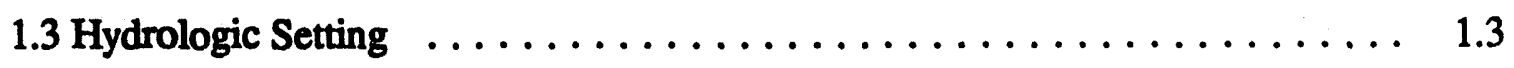

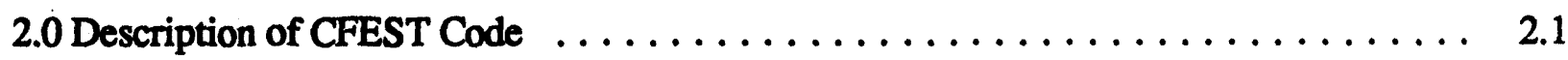

2.1 Physical Processes Modeled by CFEST $\ldots \ldots \ldots \ldots \ldots \ldots \ldots \ldots \ldots, 2.1$

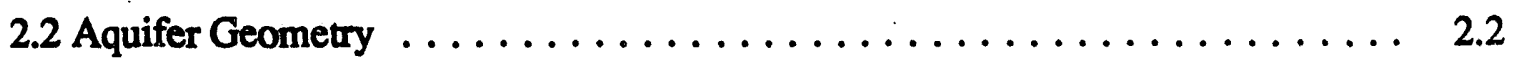

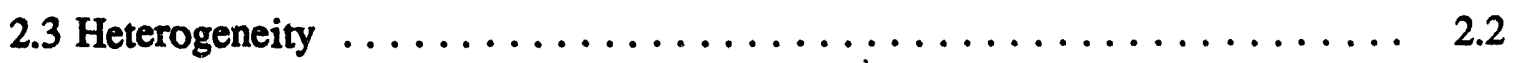

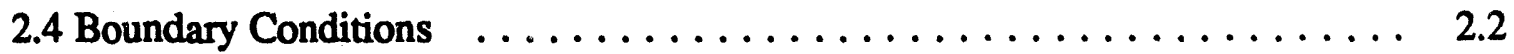

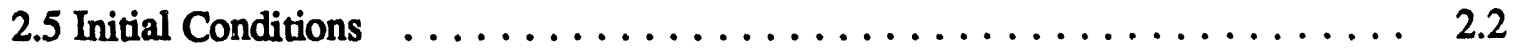

3.0 Geographic Information System/CFEST Link $\ldots \ldots \ldots \ldots \ldots \ldots \ldots \ldots .1$

4.0 Two-Dimensional Ground-Water Flow Model $\ldots \ldots \ldots \ldots \ldots \ldots \ldots \ldots .4 .1$

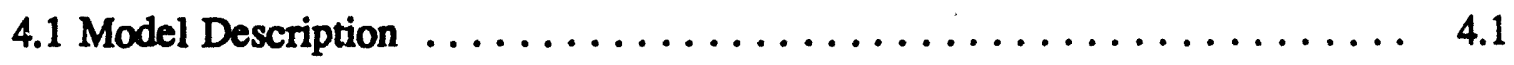

4.2 Model Application $\ldots \ldots \ldots \ldots \ldots \ldots \ldots \ldots \ldots \ldots \ldots \ldots \ldots \ldots . .4$

5.0 Three-Dimensional Hydrogeologic Conceptual Model $\ldots \ldots \ldots \ldots \ldots \ldots . .$.

6.0 Three-Dimensional Ground-Water Model $\ldots \ldots \ldots \ldots \ldots \ldots \ldots \ldots \ldots .6 .1$

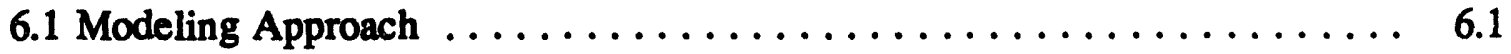

6.2 Single-layer Flow Model $\ldots \ldots \ldots \ldots \ldots \ldots \ldots \ldots \ldots \ldots \ldots .6 .1$

7.0 References $\ldots \ldots \ldots \ldots \ldots \ldots \ldots \ldots \ldots \ldots \ldots \ldots \ldots \ldots \ldots \ldots \ldots \ldots \ldots \ldots .1$

Appendix A - CFEST Input File Describing Finite-Element Grid Information and Material Properties for the Two-Dimensional Hanford Regional Flow Model .... A.1 
Appendix B - CFEST Input File Describing Flux and Time Step Information for the TwoDimensional Hanford Regional Flow Model $\ldots \ldots \ldots \ldots \ldots \ldots \ldots$ B.1

Appendix C - Plates Showing Node and Element Numbering Schemes for the CFEST Input Files Used in the Two-Dimensional Hanford Regional Flow Model

C.1 


\section{Figures}

1.1. Hanford Site Location Map $\ldots \ldots \ldots \ldots \ldots \ldots \ldots \ldots \ldots \ldots \ldots \ldots \ldots \ldots \ldots \ldots \ldots$

1.2. Structural Features of the Pasco Basin $\ldots \ldots \ldots \ldots \ldots \ldots$

1.3. Areal Distribution of Recharge for the Hanford Site as Modeled by the U.S. Geological

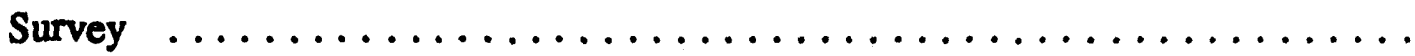

3.1. Flow Chart Showing CFEST-ARC/INFO Link as Applied to the Two-Dimensional Modeling Effort $\ldots \ldots \ldots \ldots \ldots \ldots \ldots \ldots \ldots \ldots \ldots \ldots \ldots \ldots \ldots$

4.1. Original CFEST Finite-Element Grid $\ldots \ldots \ldots \ldots \ldots \ldots \ldots \ldots \ldots \ldots \ldots \ldots \ldots \ldots$

4.2. Water Levels Predicted by Application of the Inverse Calibration Model (case 4) $\ldots$

4.3. Water Levels Predicted by Application of the Inverse Calibration Model (case 3) $\quad \ldots \quad 4.8$

4.4. CFEST Finite-Element Grid Showing Model Extension to the South $\ldots \ldots$. . . . 4.9

4.5. CFEST Finite-Element Grid Showing Boundary Conditions $\ldots \ldots \ldots \ldots \ldots . \ldots$

4.6. Hydraulic Conductivity Field Distribution as Described by the CFEST Grid $\ldots \ldots$. . 4.13

4.7. Thickness of the Unconfined Aquifer $\ldots \ldots \ldots \ldots \ldots \ldots$

4.8. Transmissivity Distribution as Described by the CFEST Grid $\ldots \ldots \ldots \ldots$. . . . 4.17

4.9. Results of Steady-State Simulations for December 1979 Using the Extended Model

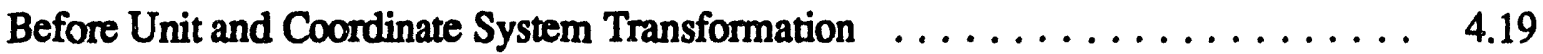

4.10. Results of Steady-State Simulations for December 1979 Using the Extended Model with Converted Units and Coordinate System 
4.11. Results of Transient Simulations for December 1989 Using the Extended Miodel Before Unit and Coordinate System Transformation $\ldots \ldots \ldots \ldots \ldots \ldots$

4.12. Results of Transient Simulations for December 1989 Using the Extended Model with Converted Units and Coordinate System $\ldots \ldots \ldots \ldots \ldots \ldots \ldots \ldots$

4.13. Water-Table Contours for the No Recharge Scenario (December 1989 Flow Field) .

4.14. Results of Particle Tracking Analyses for the No Recharge Scenario

4.15. Results of Particle Tracking Analyses for the Scenario With Recharge $\ldots \ldots$. 4.31

6.1. Current Top-of-Basalt Contour Map $\ldots \ldots \ldots \ldots \ldots \ldots \ldots \ldots \ldots \ldots .6 \ldots \ldots$

6.2. Base of the Unconfined Aquifer as Defined by the Two-Dimensional Model . . . . 6.5

6.3. Results of Steady-State Simulations for the Two-Dimensional Model $\ldots \ldots \ldots \ldots 6.7$

6.4. Results of Steady-State Simulations for the Three-Dimensional Model $\ldots \ldots \ldots \ldots 6.9$

6.5. Hydraulic Head Contours at the Base of the Aquifer for the Three-Dimensional Model 


\subsection{Introduction}

The Hanford Site Ground-Water Surveillance Project, conducted by Pacific Northwest Laboratory (PNL),(a) monitors the movement of contaminants in the ground water at the U.S. Department of Energy's (DOE) Hanford Site in southcentral Washington State (Figure 1.1). Two of the objectives of the Ground-Water Surveillance Project are to 1) identify and quantify existing, emerging, or potential ground-water quality problems and 2) assess the potential for contaminants to migrate from the Hanford Site through the ground water.

Models of the unconfined aquifer are important tools that have been used to support these objectives. In the past, most of the numerical models developed at the Hanford Site have been two-dimensional. This is an adequate representation for estimating quantities of flow, but is not adequate for predicting transport of contaminant plumes. Contaminant concentrations cannot be accurately predicted with a two-dimensional model, which assumes a constant vertical distribution of contaminants in the aquifer. This report summarizes the existing two-dimensional model used by the Ground-Water Surveillance Project for simulations at the Hanford Site and reports on the status of the three-dimensional model being developed based on the conceptual model described by Thome et al. (1993).

\subsection{History of Previous Modeling Efforts}

Numerical ground-water flow and contaminant transport models have been used previously in the Ground-Water Surveillance Project to simulate the impacts of Site operations on the rate and direction of ground-water flow and contaminant movement in the unconfined aquifer. Models were initially developed during the 1970s for use on the Hanford Site. A ground-water flow model based on the Variable Thickness Transient (VTT) code (Kipp et al. 1972) was developed and calibrated to existing data. The model was calibrated with a transient inverse calibration procedure involving an iterative routine (a streamtube approach) that used available field measurements of transmissivity (Cearlock et al. 1975). The calibrated model was used to simulate ground-water flow and predict flow paths in the unconfined aquifer.

(a) Pacific Northwest Laboratory is operated for the U.S. Department of Energy by Battelle Memorial Institute. 
A contaminant transport model based on the Multicomponent Mass Transport (MMT) code (Ahlstrom et al. 1977) was applied to simulate movement of the observed tritium plume in the unconfined aquifer between Hanford's 200-East Area and the Columbia River. The MMT code predicts contaminant transport by advection with a random component describing dispersion.

The Hanford Pathline Calculational code (Friedrichs et al. 1977) was developed and applied to predict advective transport of contaminants along selected pathlines in the unconfined aquifer that were predicted with the VTT code. A later modification of the streamtube approach, the TRANSS code, was developed by Simmons et al. (1986). The VTT and TRANSS codes were applied as part of the Hanford Defense Waste Environmental Impact Statement, and their development and application are described by DOE (1987). Other applications of VTT, MMT, and TRANSS are described by Freshley and Graham (1988).

Work was initiated in the mid-1980s to develop two- and three-dimensional models of ground-water flow based on the Coupled Fluid, Energy, and Solute Transport (CFEST) code (Gupta et al. 1987). The CFEST code was selected because of its ability to simulate both groundwater flow and contaminant transport. The development and application of the CFEST code for unconfined aquifer studies are described by Evans et al. (1988).

A steady-state inverse calibration method developed by Neuman (1980) and modified by Jacobson (1985) was applied to calibrate the two-dimensional ground-water flow model of the unconfined aquifer based on CFEST. Both the inverse calibration method and the CFEST code are based on finite elements, so they are compatible. All information for estimates of aquifer hydraulic properties (e.g., transmissivities), hydraulic heads, boundary conditions, and discharges to and withdrawals from the aquifer is included in the inverse calibration for the ground-water flow model of the unconfined aquifer. Initial efforts on the inverse calibration are described by Evans et al. (1988) and the final calibration results are described by Jacobson and Freshley (1990).

\subsection{Geologic Setting}

The Hanford Site lies within the Pasco Basin (Figure 1.2), a structural depression that has accumulated a relatively thick sequence of fluvial, lacustrine, and glaciofluvial sediments. This structural depression and nearby anticlines and synclines are formed in the underlying Columbia 
River Basalt Group, a sequence of flood basalts. The most recent basalt flow underlying much of the Hanford Site is the Elephant Mountain Member of the Saddle Mountains Basalt.

Overlying the basalt are the fluvial and lacustrine sediments of the Ringold Formation. The fluvial sequences consist of coarser-grained deposits of migrating channels and the finer-grained overbank deposits of the ancestral Columbia and/or Salmon-Clearwater river systems. Several lithologic units present only in the western portion of the Pasco Basin are the Plio-Pleistocene unit, consisting of paleosol/calcrete and sidestream sediments, and the early "Palouse" soil, an eolian sand and silt deposit. The uppermost sedimentary unit covering much of the Hanford Site is the Hanford formation, a complex series of coarse- and fine-grained layers deposited by cataclysmic floods during the last ice age. For the most part, the fine-grained sediments are found near the margins of the basin and in areas protected from the main flood currents that deposited the coarsegrained sediments. Capping the Hanford formation in mariy areas is a thin veneer of eolian sands and/or recent fluvial deposits.

As the post-basalt sediments were being deposited, the basalt was continuing to deform structurally. The basin continued to subside, and the ridges continued to rise. This process led to the formation of sedimentary units that are thickest in the center of the basin and become thin or, in places, pinch out at the anticlines. In a few places, Hanfond formation sediments directly overlie the basalt where the Ringold Formation either was never deposited or was eroded away by cataclysmic floods.

\subsection{Hydrologic Setting}

An uppermost unconfined aquifer and a sequence of confined aquifers lie beneath most of the Hanford Site. The unconfined aquifer is generally located in unconsolidated to semiconsolidated sediments overlying the basalt bedrock and the confined aquifers are generally brecciated tops of basalt flows and sedimentary interbeds located within the Columbia River Basalt. In some areas, deeper parts of the suprabasalt sediments are locally confined by overlying mud units. However, because the entire suprabasalt aquifer system is interconnected on a sitewide scale, it has commonly been referred to as the "Hanford unconfined aquifer." Aquifers located within the Columbia River Basalt are referred to as the confined aquifer system.

Ground water in both the confined and unconfined aquifer systems generally flows toward 
the Columbia River, which acts as a drain for the ground-water flow system. In some places, ground water within the confined aquifer system flows under the river, apparently toward areas of higher vertical communication between the confined and unconfined aquifers (Spane 1987; DOE 1988). Ground water in the confined aquifers comes mainly from infiltration of precipitation and streamflow within recharge areas along the periphery of the Pasco Basin (DOE 1988). With regard to development of a conceptual model for the unconfined aquifer, the confined aquifer system is important because there is a potential for significant ground-water leakage between the twc systems, particularly in areas of increased vertical permeability such as the area northeast of the 200-East Area (Graham et al. 1984).

The unconfined aquifer at Hanford lies mainly within the Ringold and Hanford formations. Because the sand and gravel facies of the Ringold Formation are generally more consolidated, contain more silt, and are less well sorted, they are about 10 to 100 times less permeable than the sediments of the overlying Hanford formation (DOE 1988). Prior to waste-water disposal operations at the Hanford Site, the uppermost aquifer was almost entirely within the Ringold Formation and the water table extended into the Hanford formation at only a few locations near the Columbia River (Newcomb et al. 1972). However, waste-water discharges have increased the water-table elevation, causing it to rise into the Hanford formation in the vicinity of the 200-East Area and in a wider area near the Columbia River.

Ground water in the unconfined aquifer at Hanford generally flows from recharge areas in the elevated region near the western boundary of the Hanford Site toward the Columbia River on the eastern and northem boundaries. The Yakima River borders the Hanford Site on the southwest and is generally regarded as a source of recharge. The Columbia River is the primary discharge area for the unconfined aquifer. Natural areal recharge from precipitation at the Hanford Site is low (Figure 1.3), probably less than $1.25 \mathrm{~cm} / \mathrm{y}(0.5 \mathrm{in} . / \mathrm{y})$ over most of the site, although a few nonvegetated areas with coarse soils may reach $5 \mathrm{~cm} / \mathrm{y}(0.2 \mathrm{in} / \mathrm{y})$ of infiltration (Gee and Heller 1985; Bauer and Vaccaro 1990). Since 1944, the artificial recharge from Hanford waste-water disposal operations has been greater than the natural recharge. As of 1989, an estimated 444 billion gallons of liquid were discharged to the ground through disposal ponds, trenches, and cribs (Freshley and Thome 1992). 


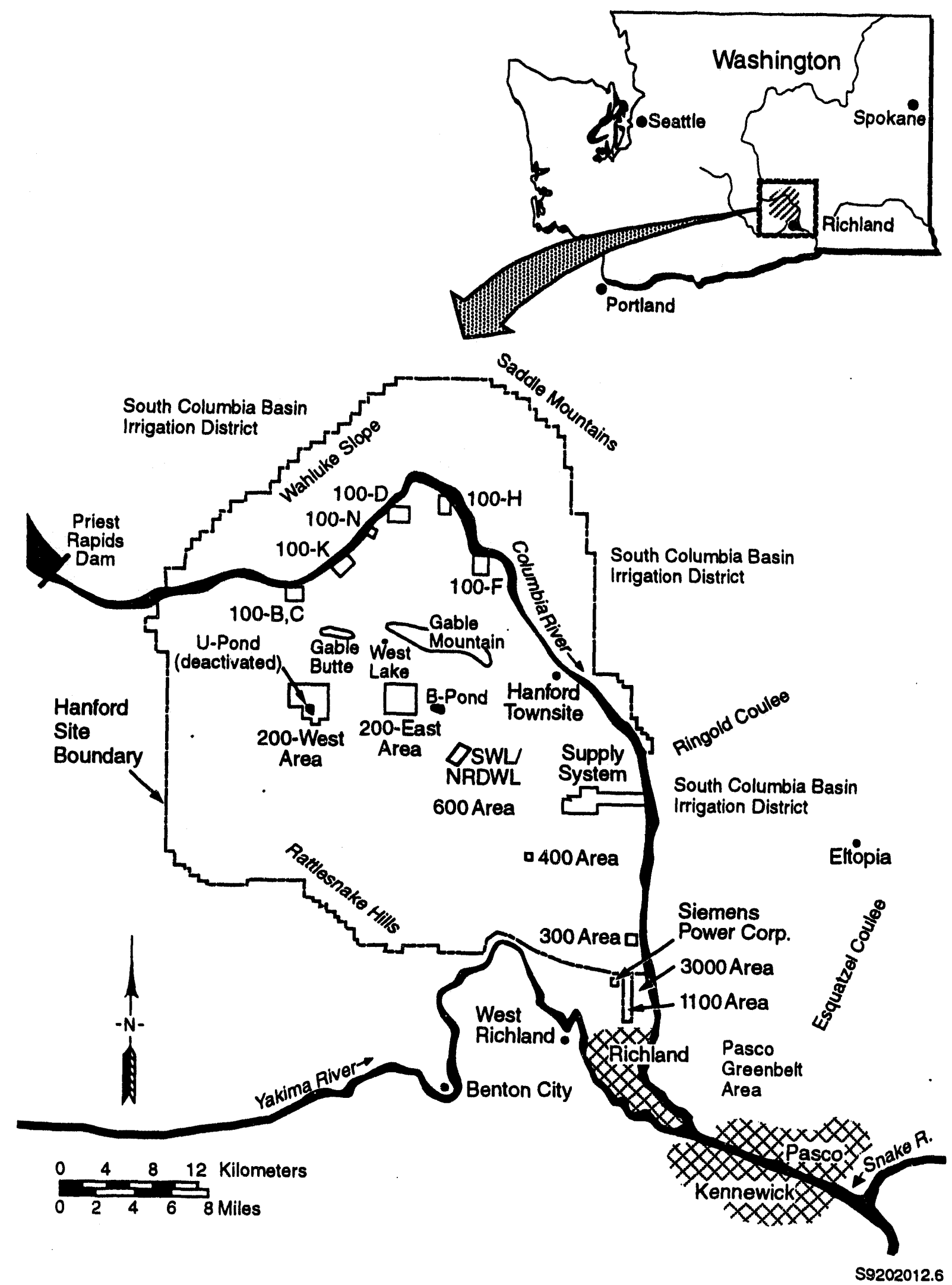

Figure 1.1. Hanford Site Location Map 


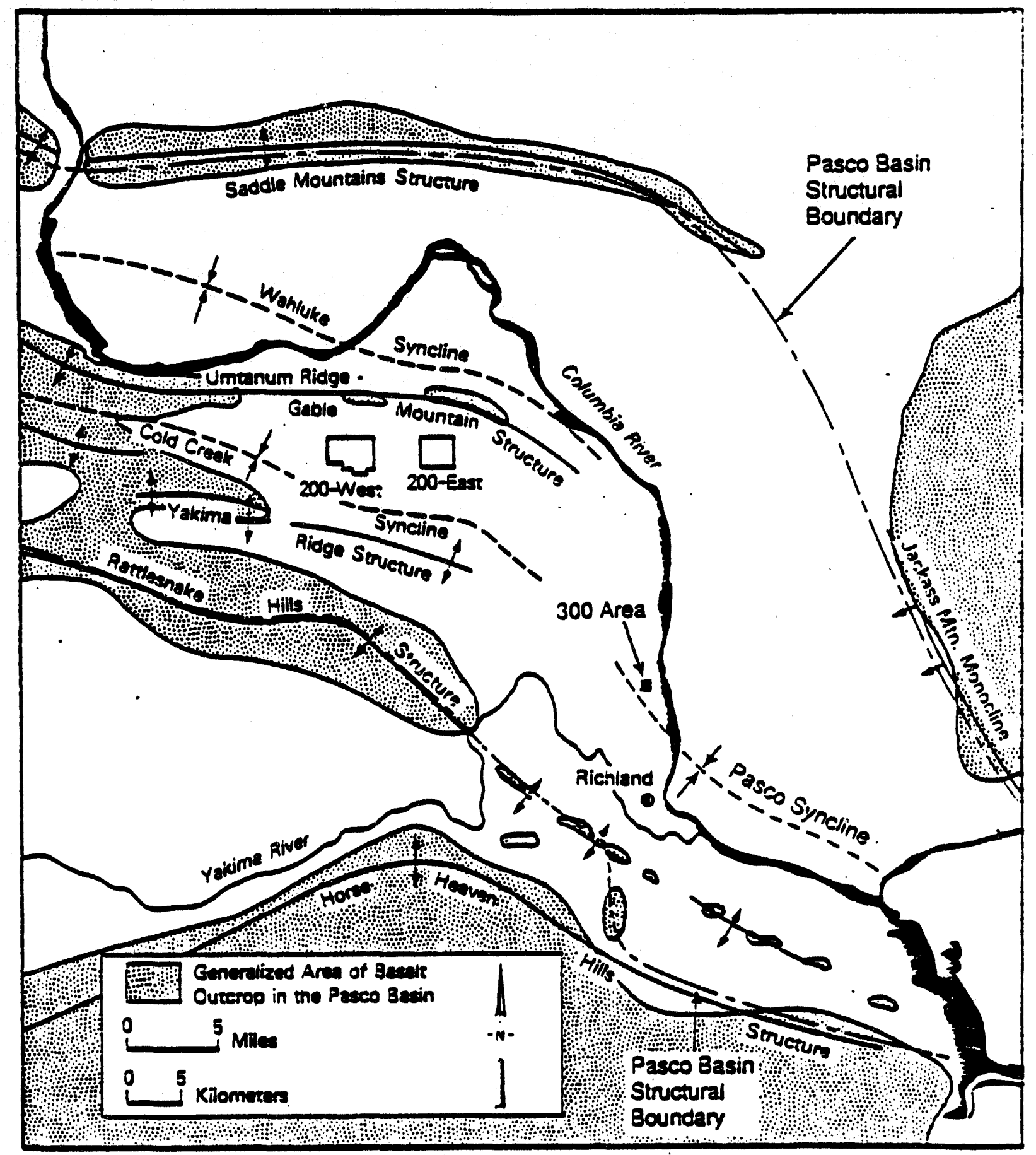

Figure 1.2. Structural Features of the Pasco Basin 


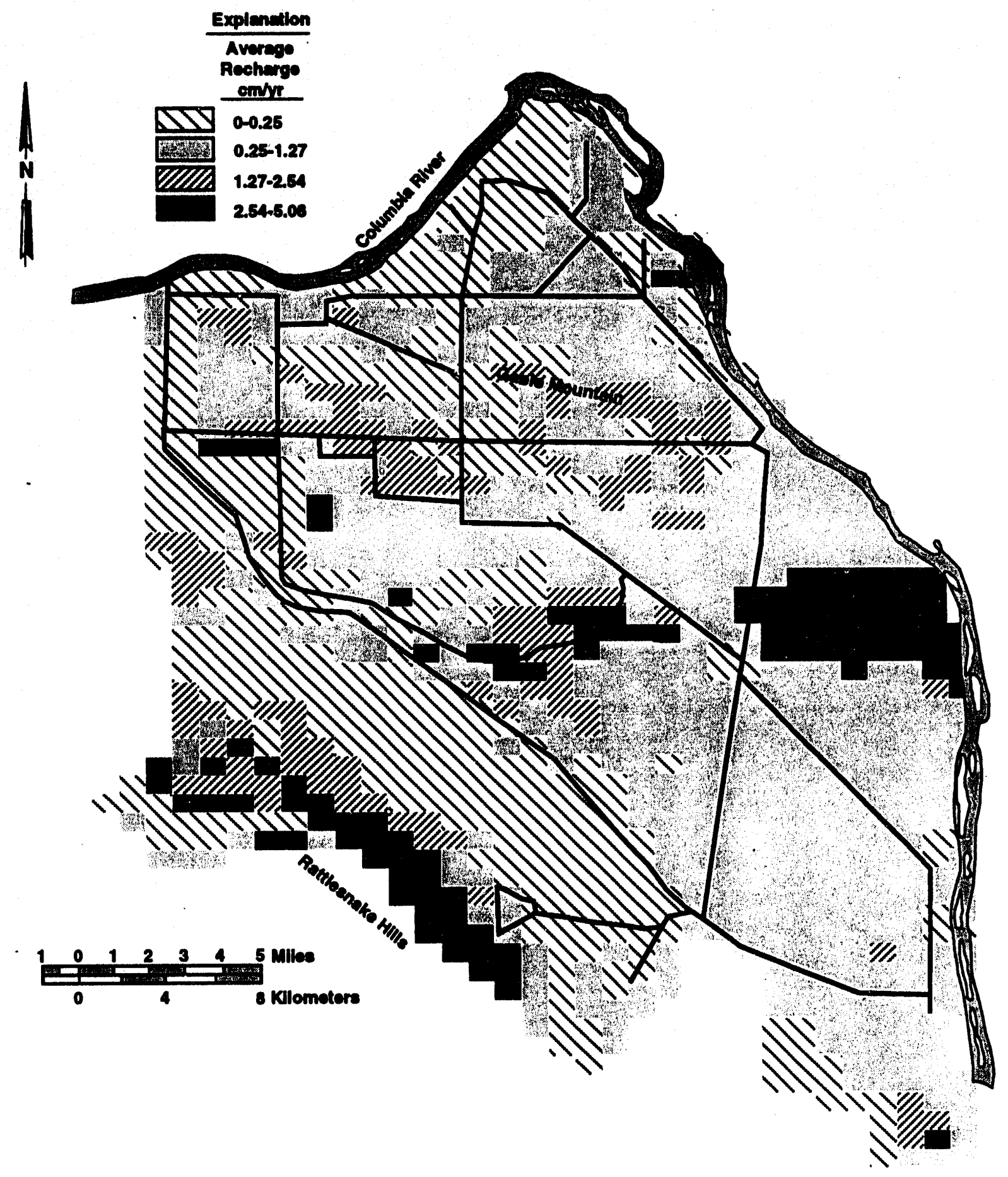

$\$ 9208070.1$

Figure 1.3. Areal Distribution of Recharge for the Hanford Site as Modeled by the U.S. Geological Survey (Bauer and Vaccaro 1990) 


\subsection{Description of CFEST Code}

The CFEST [Coupled Fluid, Energy, and Solute Transport (Gupta et al. 1987)] code was originally designed to support the radioactive waste repository investigations sponsored by DOE's Civilian Radioactive Waste Management Program. It has also been effectively used by the chemical waste management community for conducting exposure assessments, evaluating remediation alternatives, and designing extraction and control systems for aquifers.

The CFEST software library was extensively tested and brought under strict software Quality Assurance/Quality Control procedures by the Office of Nuclear Waste Isolation (ONWI). A supercomputer version (CFEST-SC) was developed to run on all major Unix work stations (Cole et al. 1988). The CFEST output is now graphically displayed using the ARC/INFO geographic information system (GIS).

\subsection{Physical Processes Modeled by CFEST}

The CFEST code solves partial differential equations for fluid pressure, temperature, and solute concentration for multilayered, confined hydrologic systems using the finite-element method. Options exist to solve the equations for pressure, temperature, and solute concentration in either an uncoupled or a coupled form. Fluid properties of density and viscosity are used to couple the equations for simulations requiring variable density solutions. Solution of the system of coupled equations is based on linearization, with the latest iteration of known pressure, temperature, and solute concentration used to compute fluid and aquifer properties for the next iteration.

Phreatic solutions can be computed for the uncoupled equations through an iterative technique that adjusts the saturated thickness so that the calculated head is the top of the system. The user has the option to solve for any or all of the dependent variables. The code is designed to simulate transient or steady-state fluid flow coupled with energy and/or solute transport. Since Hanford simulations currently do not consider differences in fluid density or viscosity, only the uncoupled equation option is used for Hanford Site simulations. 


\subsection{Aquifer Geometry}

In the Cartesian coordinate system, the code can be used for simulation in a horizontal plane, a vertical plane, or a fully three-dimensional regime. An option also exists for the axisymmetric analysis of a vertical cross section.

The CFEST finite-element formulation has the capability to model discontinuities, major breaks in slope or thickness, and fault zones in individual hydrogeologic units. Surface-water bodies (lake, river, seashore), recharge or pumping wells, and variations in major land uses may be modeled using the appropriate grid (node locations).

\subsection{Heterogeneity}

The code models heterogeneity in aquifer permeability and porosity. Anisotropy (co-linear with the Cartesian coordinates) is also accommodated. The variation in the hydraulic properties may be described homogeneously within layers or heterogeneously on an elemental basis for aquifers exhibiting a certain degree of geologic complexity.

\subsection{Boundary Conditions}

The code includes options for both constant and time-variant Dirichlet and Neumann boundary conditions. The Dirichlet and Neumann boundary conditions can be specified individually for each dependent variable. For example, a given node may have a specified concentration (Dirichlet) as well as a specified fluid flux (Neumann).

\subsection{Initial Conditions}

The user can specify the following initial conditions:

a) Hydraulic Head or Pressure -- Constant values for hydraulic head or pressure are specified throughout the region for cases of constant and variable density. 
b) Temperature -- Constant temperature, temperature as a function of depth, or independent nodal values of temperature may be specified at each node.

c) Concentration - Constant or independent nodal values of concentration may be specified at each node. 


\subsection{Geographic Information System/CFEST Link}

A geographic information system (GIS) consists of tabular databases and geographic databases (e.g., well locations or facilities maps) linked together with relational database software. This enables the user to easily perform sophisticated spatial data analyses that might take hours or days using conventional methods.

The Ground-Water Surveillance Project uses a commercial GIS package, ARC/INFO, to support its database management and mapping needs. The display and analysis capabilities of a GIS are well suited to the size and diversity of databases being generated at the Hanford Site. The ability to visually inspect large databases through a graphical analysis tool provides a stable foundation for site assessments and ground-water modeling studies. The GIS capability of color coding data greatly aids in the visual recognition of data trends, particularly in the inspection of large numbers of chemical and radiological measurements.

The ARC/INFO GIS has been integrated with the CFEST ground-water modeling library to support the Ground-Water Surveillance Project. This GIS/modeling capability arose from the need for effective database management and graphical tools to support ongoing environmental activities coupled with the need for more effective graphical interfaces for the ground-water models. A series of ARC/INFO macro routines and FORTRAN utility programs have been developed to allow the ARC/INFO - CFEST interface to include the following capabilities:

- Extract chemistry or radiological data from the Hanford Environmental Information System database and prepare contour maps of the ground-water plumes to be used as initial . conditions for the CFEST transport model

- Develop planar and cross-sectional maps of the geohydrologic conceptual model by interfacing surface generation algorithms with the geologic database

- Develop finite-element grids and input hydrologic and chemical parameters to the CFEST input files

- Produce report-quality or cartographic-quality maps based on CFEST output.

Figure 3.1 depicts the information flow between the individual CFEST computational modules and post-processors, the FORTRAN utility programs, and the ARC/INFO macro routines as applied to the two-dimensional modeling efforts. For example, an ARC/INFO macro may be 
used to select elements that represent starting points for particle travel analyses. A FORTRAN utility program will then generate a command file used to execute the CFEST travel path module. Another ARC/INFO macro has been written to create a triangular irregular network surface from CFEST output, from which contour maps can be generated. In addition, several other macro routines have been developed to enhance the output capability and efficiency of the GIS. These include routines that allow 1) plotting of results over a consistent set of Hanford base maps and 2) creating either black and white or color encapsulated Postscript file formats. Additional ARC/INFO macros for grid generation and parameter assignment will be used in support of the three-dimensional model development. 


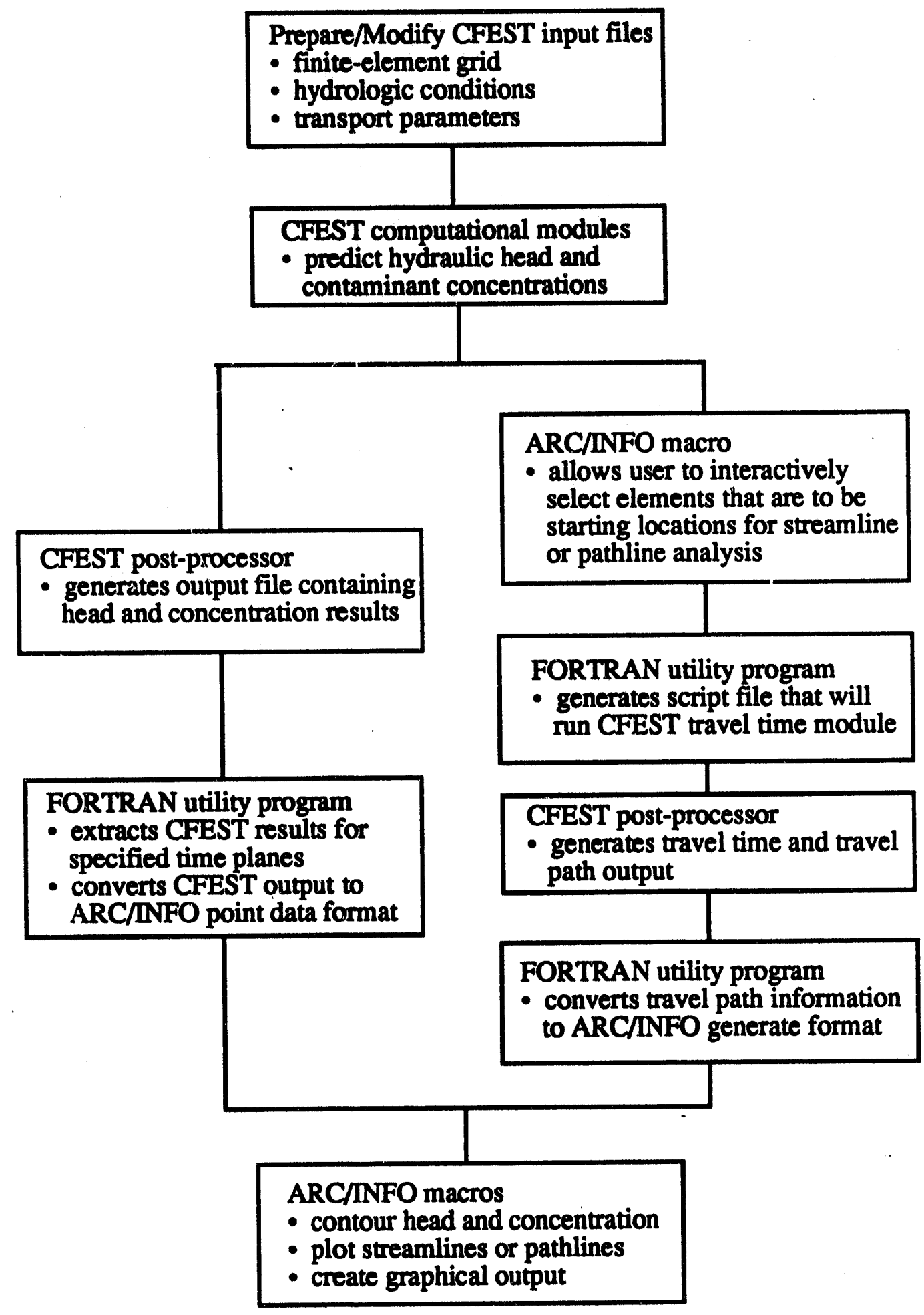

Figure 3.1. Flow Chart Showing CFEST-ARC/NFO Link as Applied to the Two-Dimensional Modeling Effort 


\subsection{Two-Dimensional Ground-Water Flow Model}

The current configuration of the two-dimensional ground-water flow model is described below. Recent enhancements include extending the model to the south and converting the units and the coordinate system. An example application of the model, consisting of pathline analyses performed for two ground-water flow system scenarios, is presented below.

\subsection{Model Description}

Jacobson and Freshley (1990) used an inverse method to update the transmissivity field for the Hanford Site originally generated by Cearlock et al. (1975) for the VTT code. This updated distribution of transmissivity values was used as input for the CFEST code to model ground-water flow and transport at the Hanford Site. Figure 4.1 shows the original finite-element grid generated for the CFEST code. The grid, consisting of 966 nodes and 878 elements, was designed to provide detail around waste disposal facilities and in areas where hydraulic conductivity changes significantly over small distances. Jacobson and Freshley (1990) describe the sources of data used in the inverse calibration. December 1979 was determined to be the time most representative of steady-state conditions. Several cases were run to determine how best to represent boundary conditions in the vicinity of Cold Creek and to evaluate the effects of areal natural recharge. Jacobson and Freshley (1990) reported that the cases with a prescribed head boundary condition in the vicinity of Cold Creek (cases 3 and 4) produced a better match to observed water levels than the two cases with a constant flux boundary condition at Cold Creek (cases 1 and 2). Case 4 included areal natural recharge to the aquifer and produced a slightly better fit to the observed water levels (Figure 4.2) than case 3, which did not include areal recharge (Figure 4.3). However, all cases ignored any communication with the basalt aquifers.

Transient simulations were run with CFEST based on the transmissivity distribution from the results of case 4 for a 6-year period from 1980 to 1985 . The time step for these simulations is 1 month. Therefore, data for liquid waste discharges to the ground are required for monthly intervals. These data are taken from operating contractor reports (e.g., Brown et al. 1990). In addition to data describing effluent discharges, transient simulations require specification of storage coefficients for the unconfined aquifer. There are relatively few measurements of storativity for the unconfined aquifer, therefore, a constant value of 0.1 , taken from the VTT model, was assumed. 
This value was divided by the thickness at each element to provide CFEST with storage values in units of $1 / \mathrm{L}$ for each element. The results were compared to measured values and are discussed by Jacobson and Freshley (1990).

The transmissivity distribution from case 3 was used for project simulations because of uncertainty in the availability of good areal recharge data for transient simulations. Plans exist for evaluating recharge to the unconfined aquifer at the Hanford Site and incorporating the results into the model. Several modifications and additions have been made to the model based on the case 3 transmissivity field to create the current two-dimensional model used for simulations at the Hanford Site. To investigate effects of Hanford operations near the Richland well field and the 3000 Area, an extension of the model boundary was necessary. The finite-element grid was extended southward in 1991 to include the 3000 and 1100 areas (Figure 4.4). The southern boundary of the extended finite-element grid consists of the Yakima River and its confluence with the Columbia River. The grid resolution in the extended region of the model is fairly coarse because the available information on the hydrogeology and on activities in that area did not warrant finer discretization. Prescribed head boundary conditions along the Yakima and Columbia rivers were taken from the VTT model. Values for hydraulic conductivity, aquifer thickness, and specific yield were also taken from the VTT model. The extended region finite-element grid contains 997 nodes and 904 elements. In addition, data for waste disposal facility discharges were updated to include the period through 1990.

In 1993, the model was converted to the Lambert metric coordinate system to make it compatible with other Hanford Site activities. Units for the model were also converted to meters, allowing easier comparison of model results to measured values. A review of the model also indicated that some of the boundaries of the original CFEST grid did not match the updated Columbia River location maps or current interpretations of basalt outcrops above the water table. Node locations were moved to more accurately represent aquifer boundaries. The adjusted finiteelement grid and boundary conditions are shown in Figure 4.5. The hydraulic conductivity field (Figure 4.6) is derived from the aquifer thickness (Figure 4.7) and the transmissivity field (Figure 4.8) generated by the inverse calibration (Jacobson and Freshley 1990). Steady-state and transient simulations were performed with the revised model and compared with results from the original model (Figures 4.9 through 4.12). The original model results were calculated in the original units and converted to metric units just before contouring to allow direct comparison with the revised model. The CFEST input files for transient simulations as well as plates showing the numbering 
scheme for nodes and elements are provided in Appendixes A, B, and C [see Cole et al. (1988) for input file interpretation].

\subsection{Model Application}

A pathline analysis was performed as part of the evaluation of the potential for the tritium plume to migrate to the immediate vicinity of the City of Richland well field. A pathline analysis tracks hypothetical water particles through a flow field generated by a ground-water flow simulation. Contaminant transport calculations were not performed. Therefore, dispersion, which would cause lateral spreading of the plume beyond particle pathlines, was not considered. Flow paths were calculated for particles on the southem boundary of the tritium plume based on two scenarios for the future condition of the ground-water flow system. The two simulations were based on initial conditions that represented the December 1979 steady-state flow field determined from the results of the inverse calibration done by Jacobson and Freshley (1990). Transient flow was simulated in monthly time steps beginning in December 1979 and proceeding through the end of 1989 (a total of 10 years). One scenario assumed recharge at the Richland well field during the 10-year period, and the other assumed no recharge at the Richland well field during the 10-year period. The two scenarios were assumed to bracket future behavior of the ground-water flow regime near the Richland well field. For each scenario, particle tracking analyses assumed that December 1989 flow conditions remained constant. Various locations near the boundary of the tritium plume were chosen as starting points for the tracking of water particles through the flow system to predict the potential movement of the tritium plume. The particle paths were tracked until they reached a model boundary.

The Yakima River recharges the unconfined aquifer in the southern portion of the model, creating a hydraulic gradient from west to east. This gradient can be seen in Figure 4.13, which shows the contoured water table for the scenario assuming no recharge at the Richland well field. Upon reaching the southern portion of the model, particles moving from the Site in a southeast direction follow paths into the Columbia River. When recharge occurs at the Richland well field, a ground-water mound forms, affecting the west-to-east gradient in the area surrounding the well field (Figure 4.11). Figure 4.14 shows the results of the particle tracking analyses for the scenario that assumes no recharge at the Richland well field. In this case, particles originating from locations representing the edge of the existing tritium plume exit into the Columbia River at 
locations south of the 300 Area and north of the Richland well field. The particle tracking results for the scenario that assumes recharge occurs at the Richland well are shown in Figure 4.15. For this scenario, the particles exit into the Columbia River even farther north (near the south end of the 300 Area ) because of localized changes in the gradient caused by the ground-water mound near the Richland well field. 


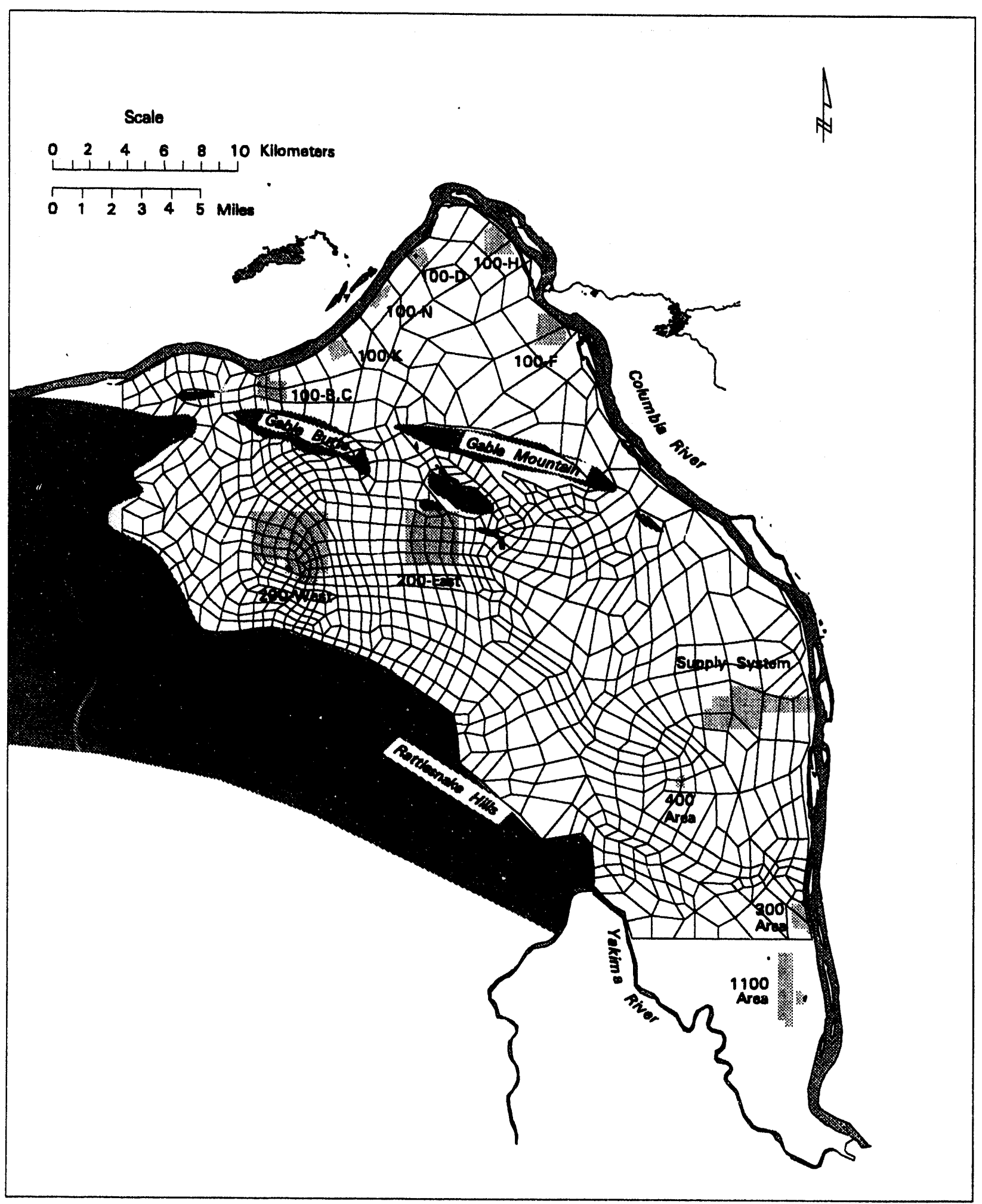

Figure 4.1. Original CFEST Finite-Element Grid 


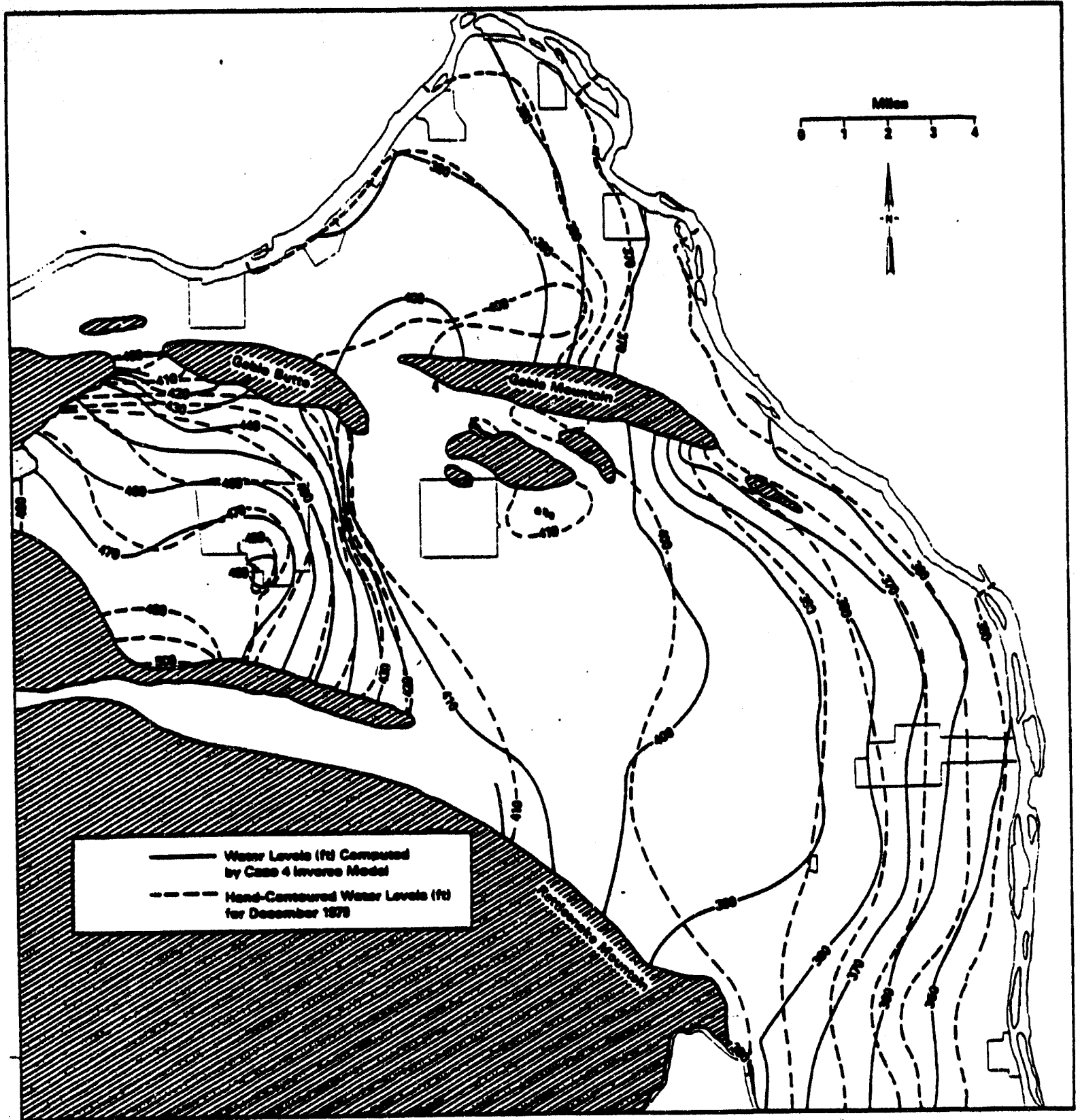

Figure 4.2. Water Levels Predicted by Application of the Inverse Calibration Model [case 4 from Jacobson and Freshley (1990)] 


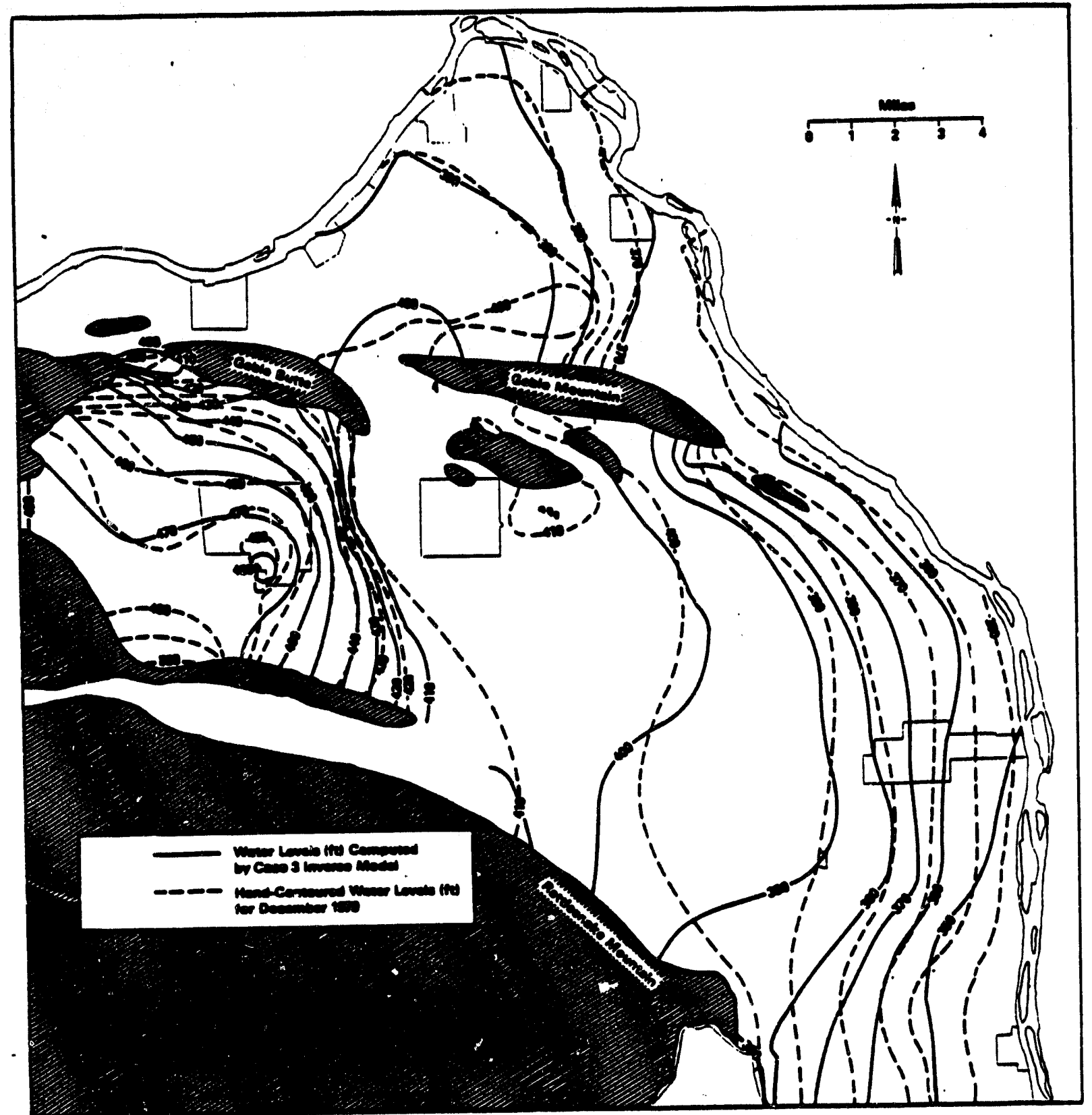

Figure 4.3. Water Levels Predicted by Application of the Inverse Calibration Model [case 3 from Jacobson and Freshley (1990)] 


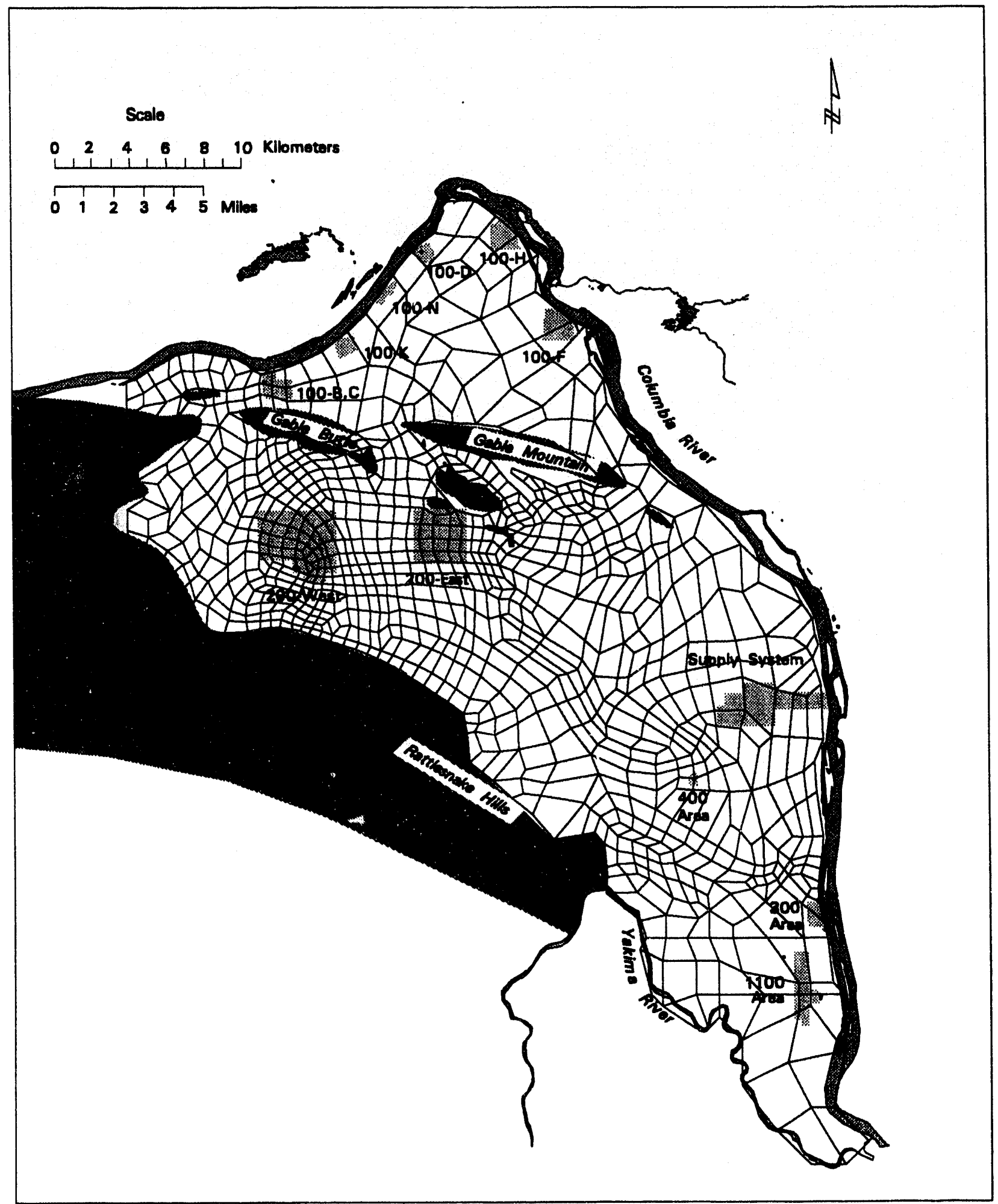

Figure 4.4. CFEST Finite-Element Grid Showing Model Extension to the South 


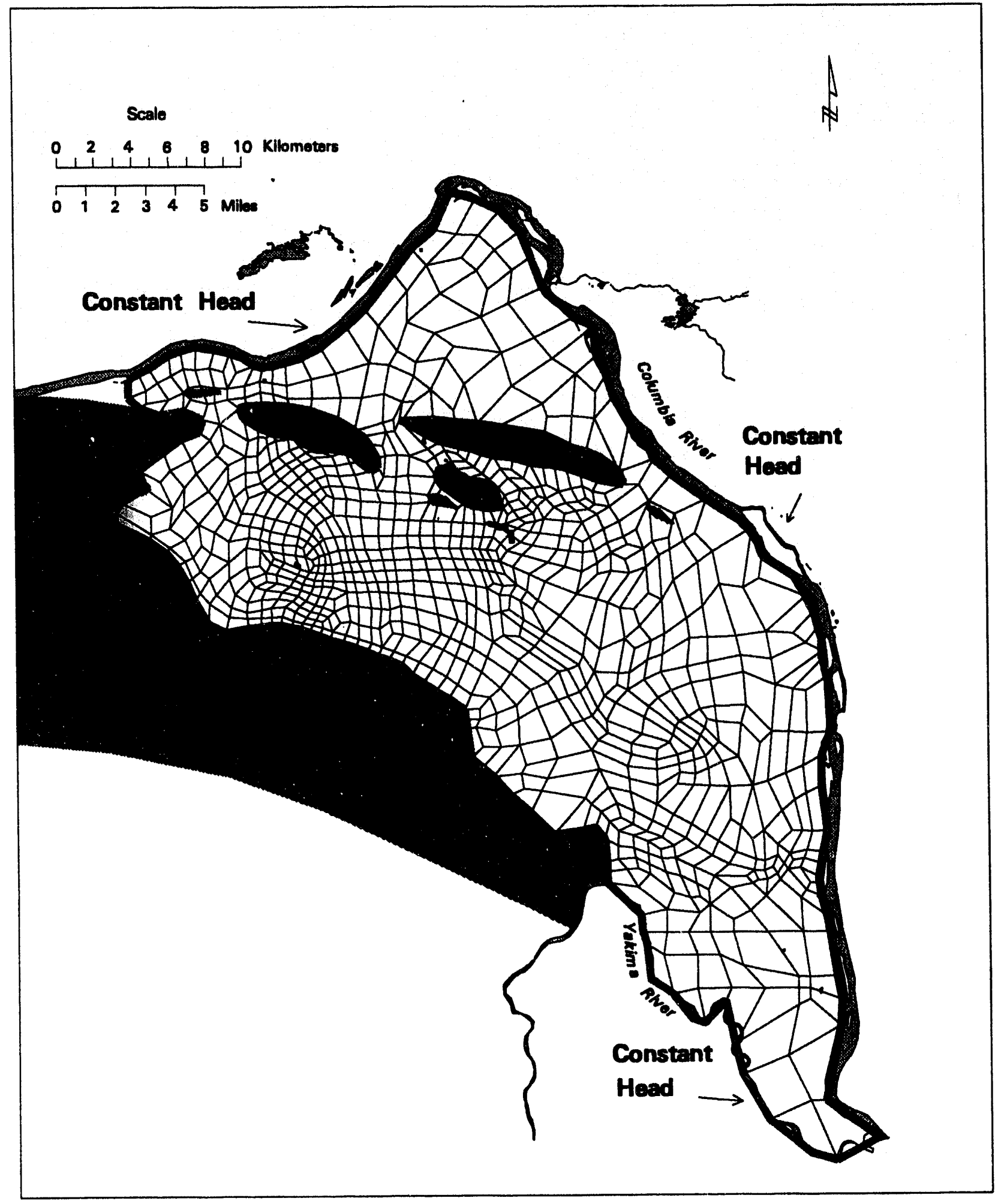

Figure 4.5. CFEST Finite-Element Grid Showing Boundary Conditions 


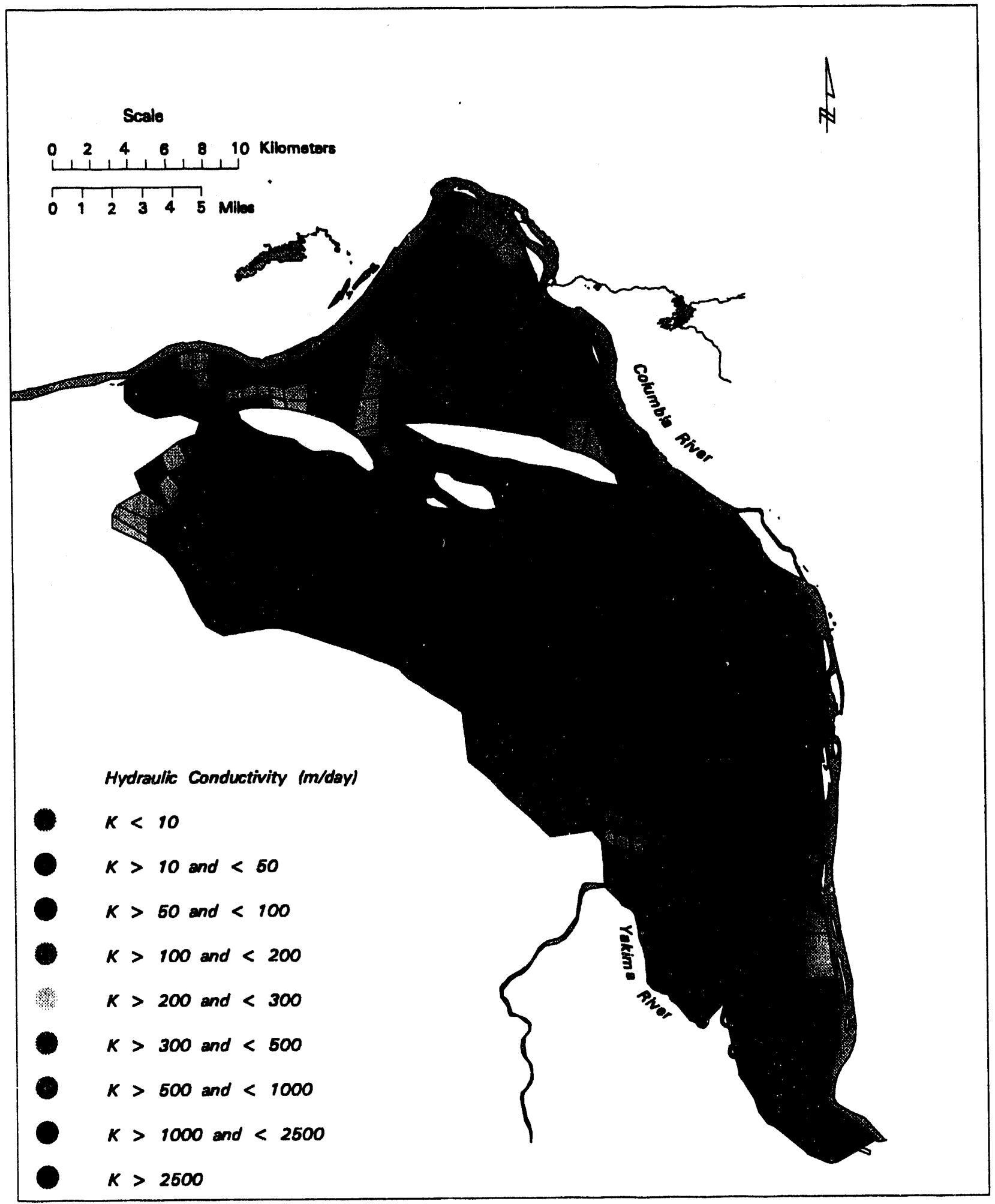

Figure 4.6. Hydraulic Conductivity Field Distribution as Described by the CFEST Grid 


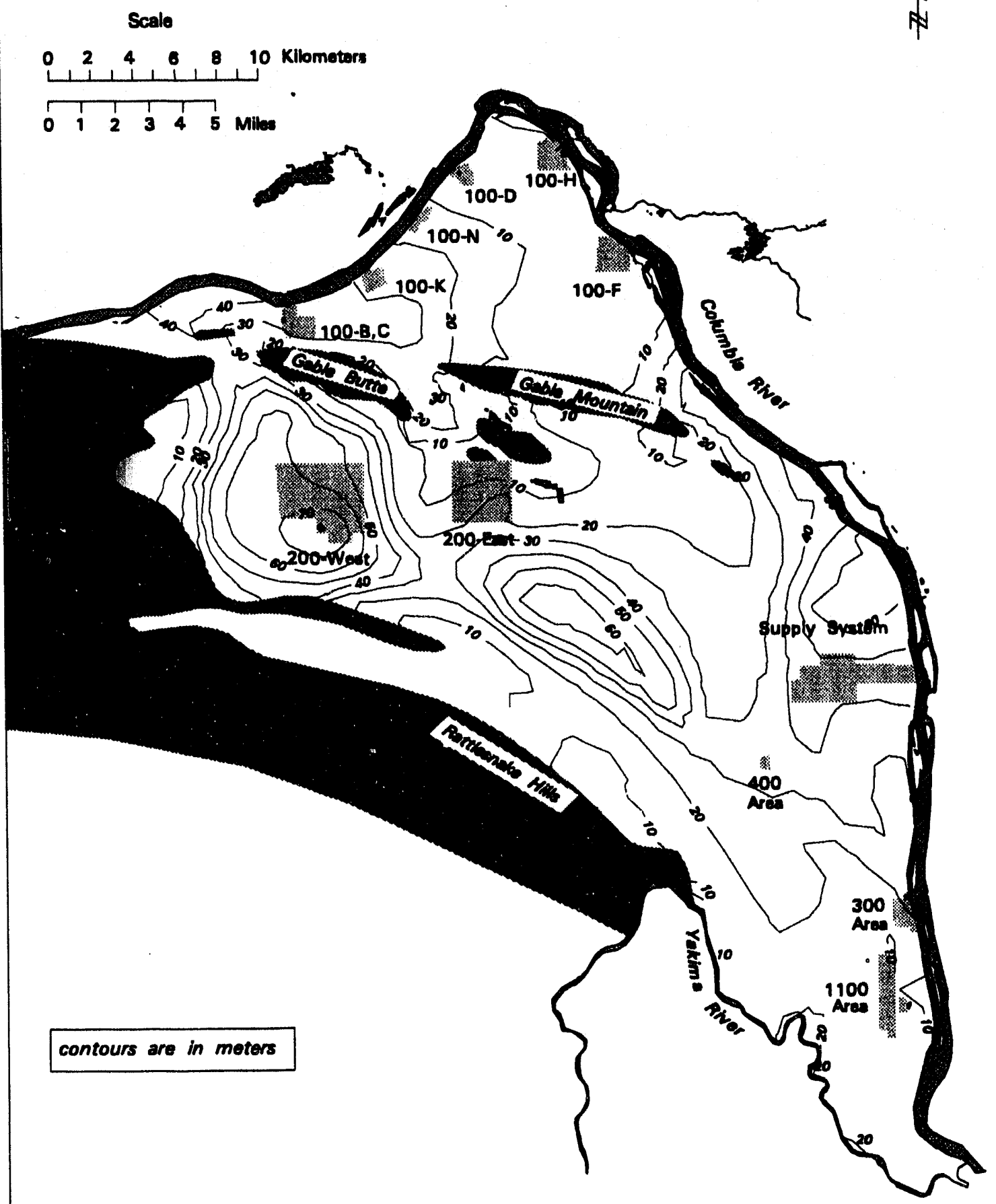

Figure 4.7. Thickness of the Unconfined Aquifer 


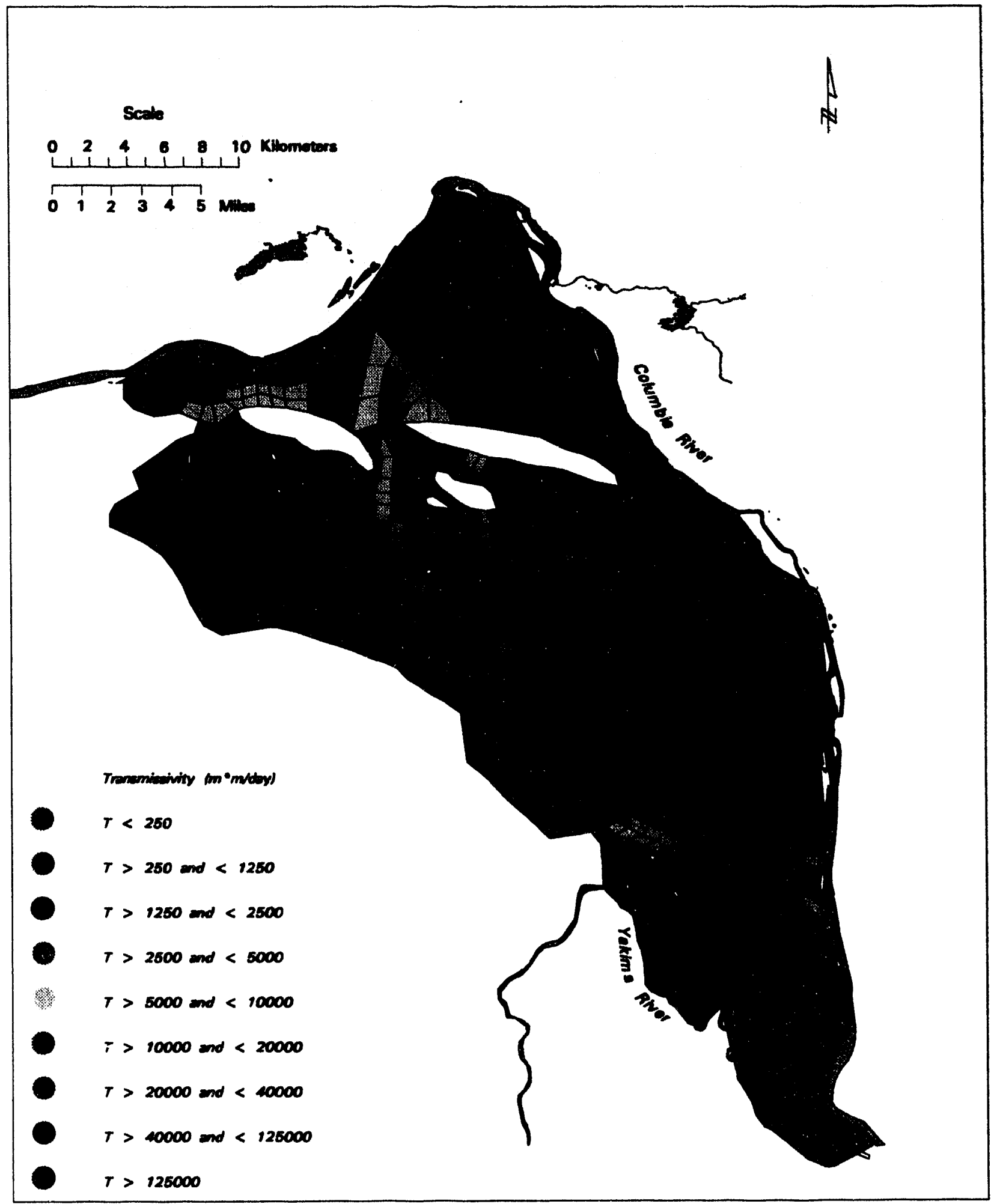

Figure 4.8. Transmissivity Distribution as Described by the CFEST Grid 


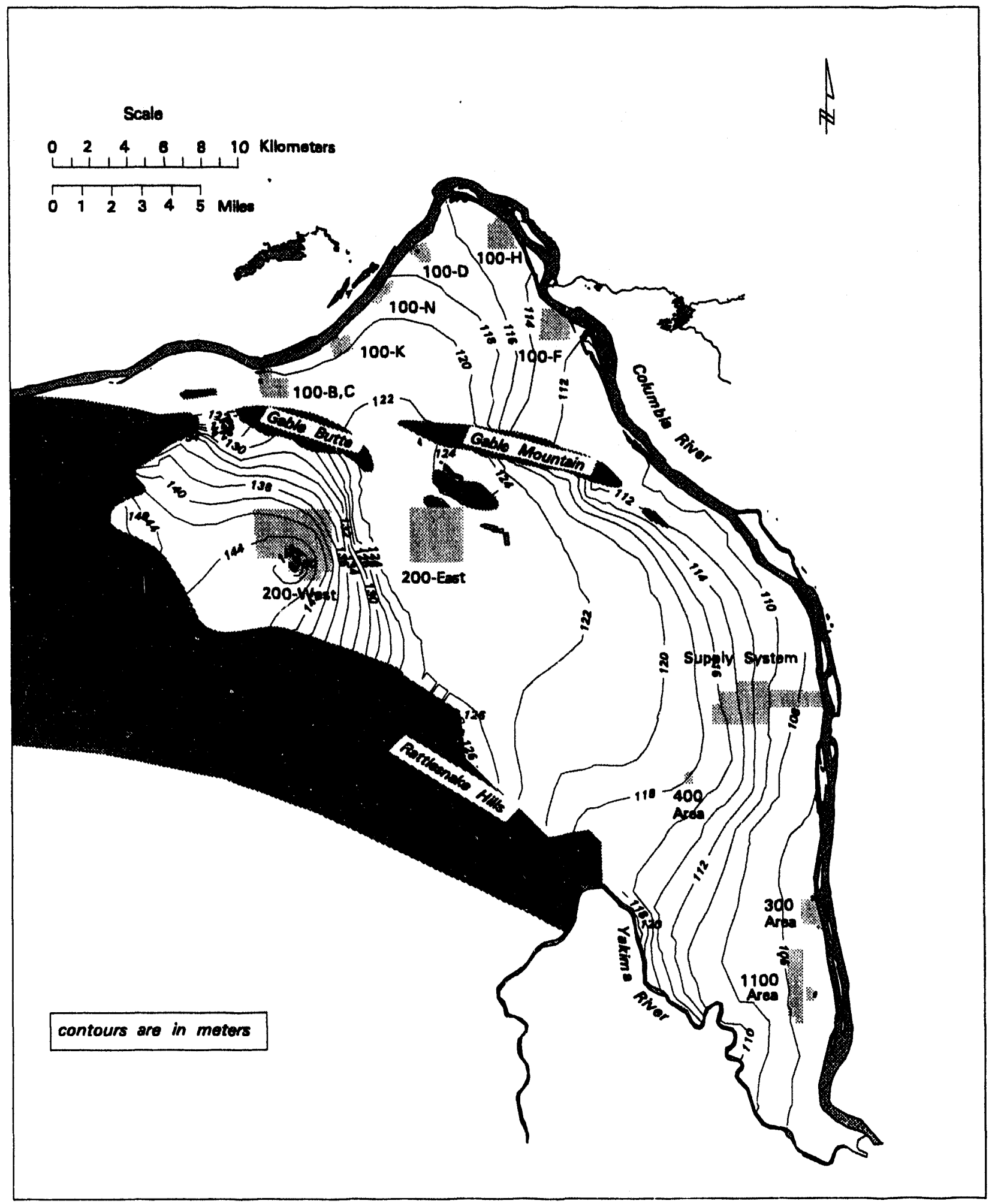

Figure 4.9. Results of Steady-State Simulations for December 1979 Using the Extended Model Before Unit and Coordinate System Transformation 


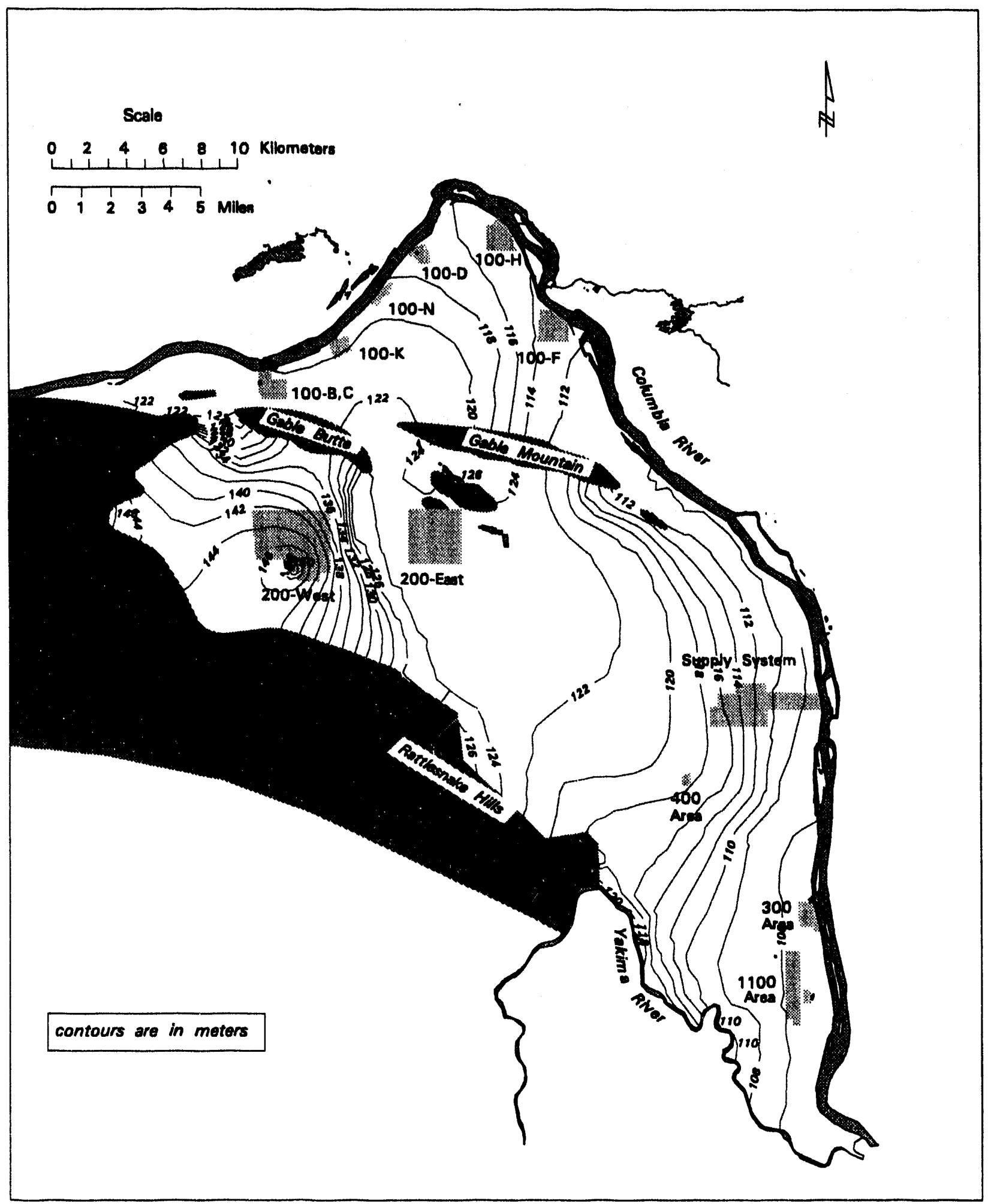

Figure 4.10. Results of Steady-State Simulations for December 1979 Using the Extended Model with Converted Units and Coordinate System 


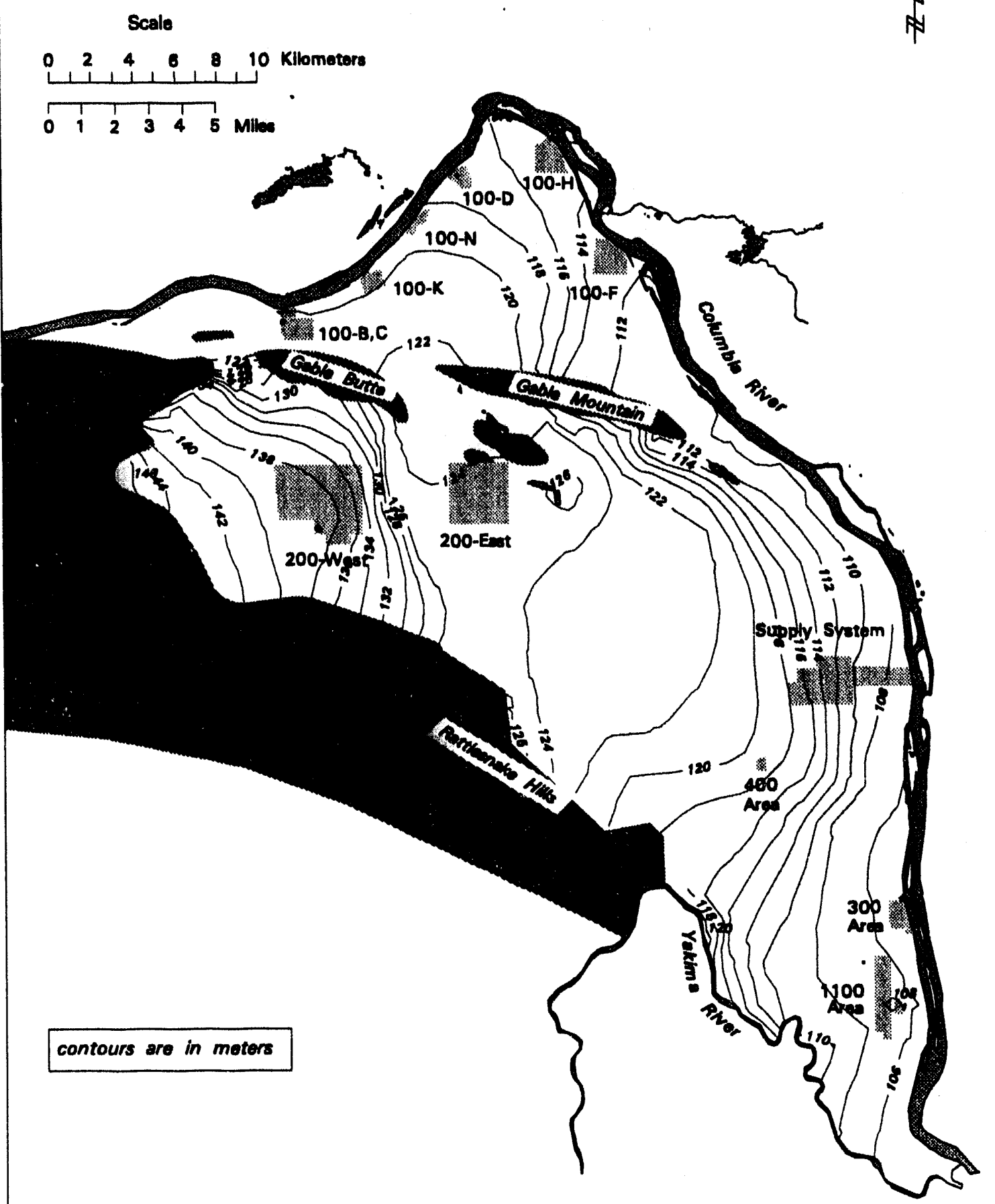

Figure 4.11. Results of Transient Simulations for December 1989 Using the Extended Model Before Unit and Coordinate System Transformation 


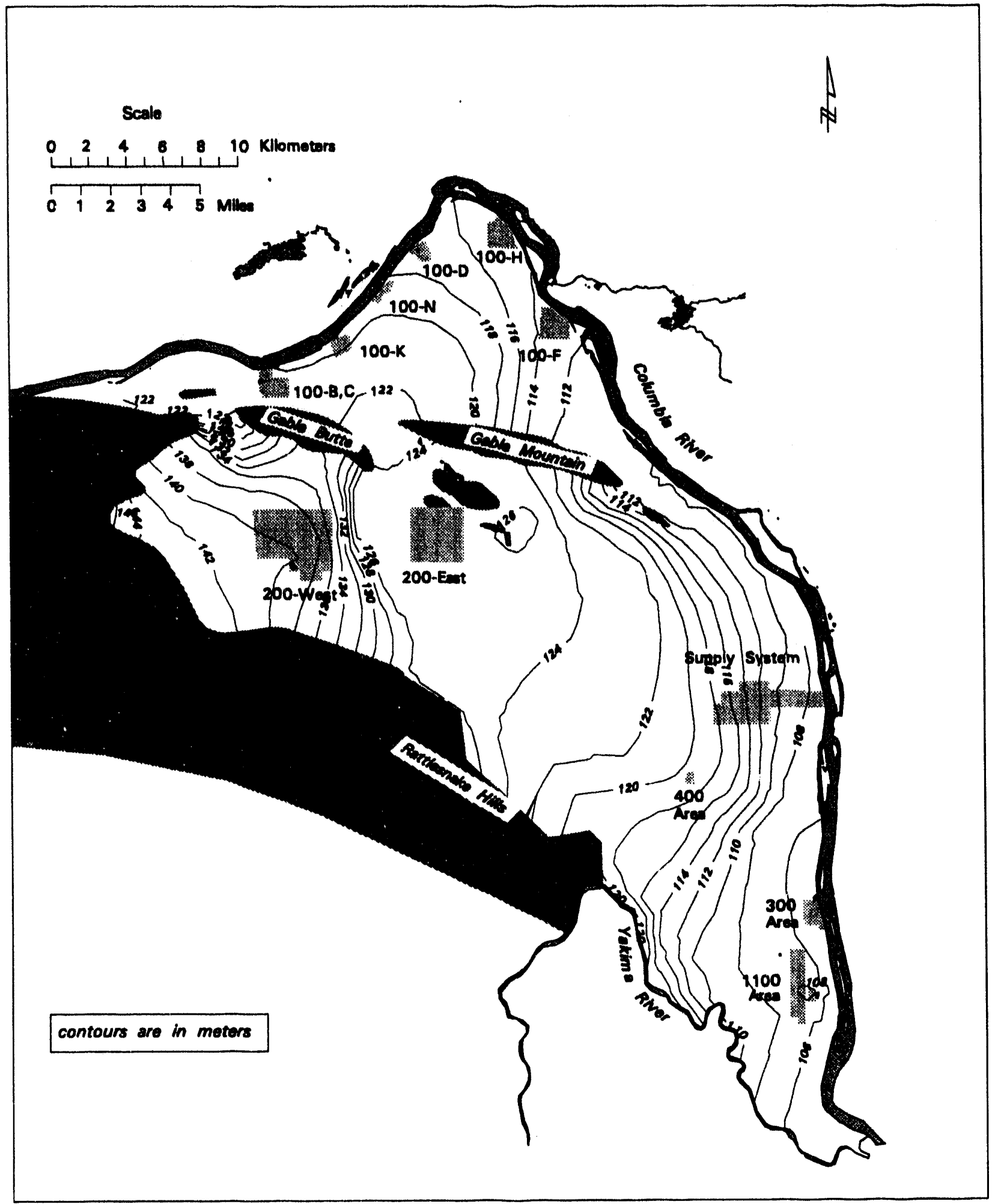

Figure 4.12. Results of Transient Simulations for December 1989 Using the Extended Model with Converted Units and Coordinate System 


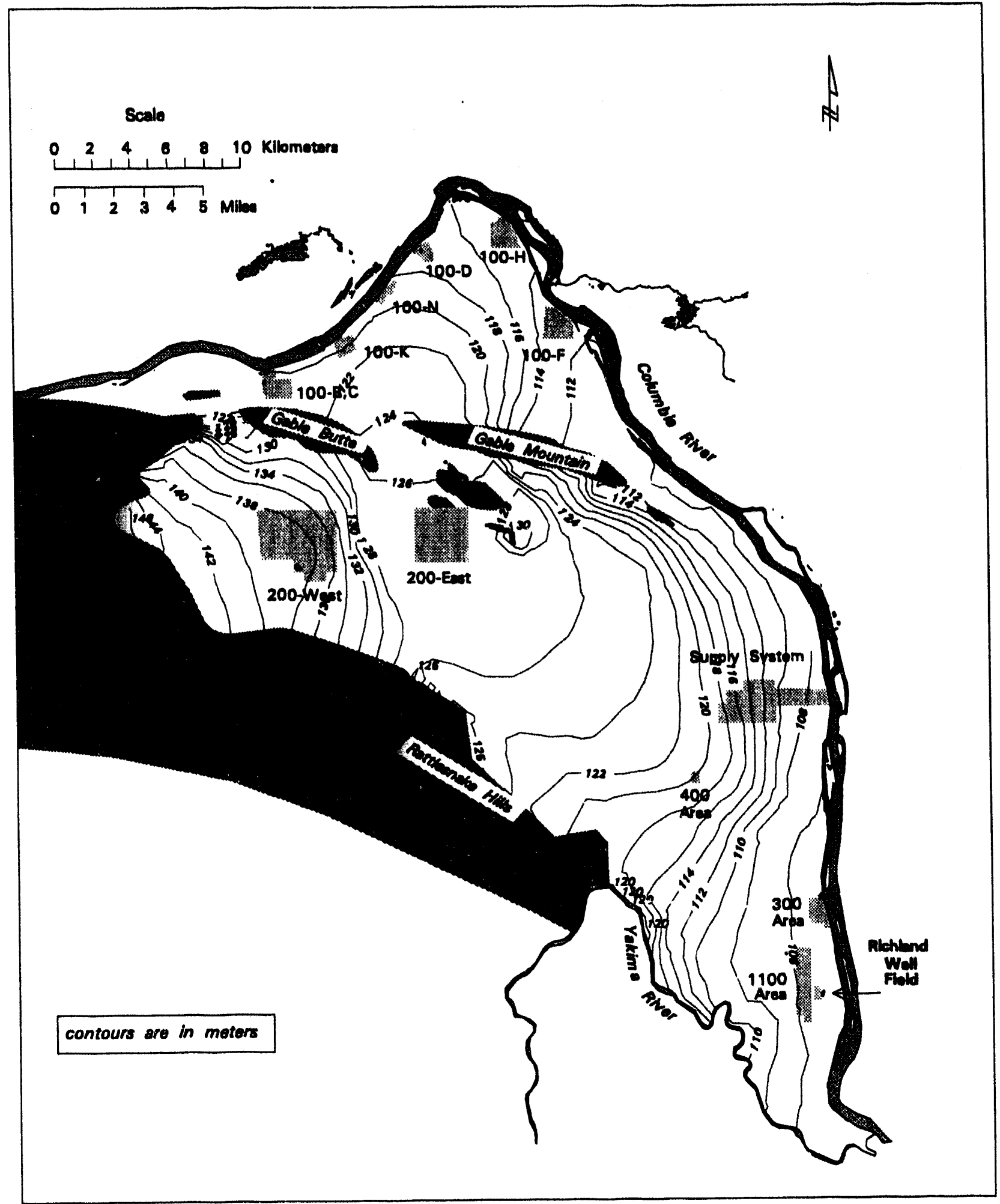

Figure 4.13. Water-Table Contours for the No Recharge Scenario (December 1989 Flow Field) 


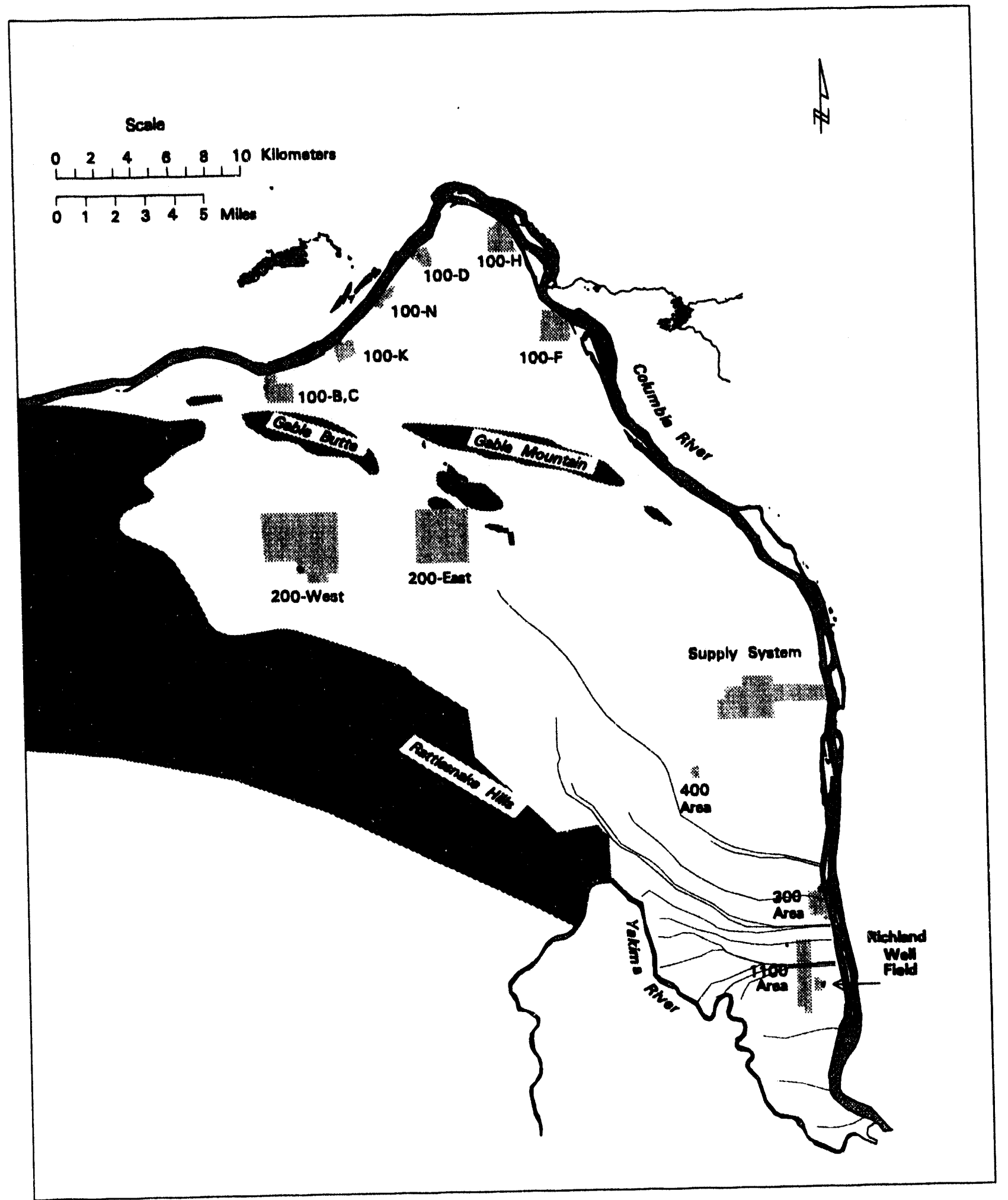

Figure 4.14. Results of Particle Tracking Analyses for the No Recharge Scenario 


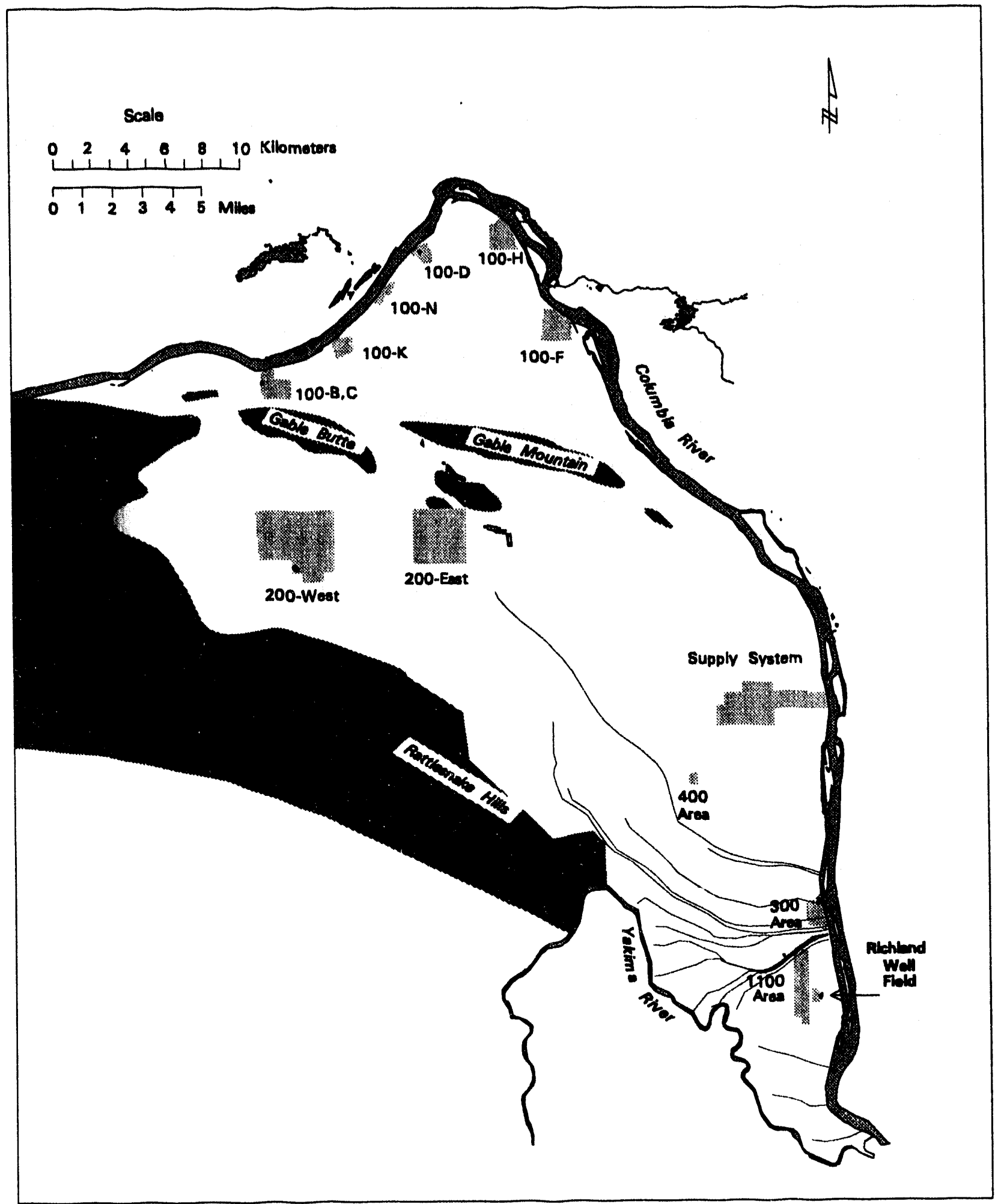

Figure 4.15. Results of Particle Tracking Analyses for the Scenario With Recharge 


\subsection{Three-Dimensional Hydrogeologic Conceptual Model}

Before a numerical model can be built and used to simulate ground-water flow and contaminant transport on the Hanford Site, a conceptual model describing the flow system must be developed. The conceptual model describes the geometry of the flow system, defines hydraulic properties throughout the model region, describes boundary conditions, and establishes initial conditions for variables such as hydraulic head and contaminant concentrations. For the threedimensional conceptual model, describing flow system geometry involves defining the orientation and extent of hydrogeologic layers that make up the unconfined aquifer system. Constant hydraulic properties may be defined for a particular layer, or a spatial distribution of properties may be assigned to the layer. Both horizontal and vertical hydraulic conductivities must be defined to support the three-dimensional model because vertical flow is important. Boundary conditions include perimeter boundaries, which are usually defined as prescribed head or prescribed groundwater flux, and boundaries for the upper and lower surface of the aquifer. Because the model describes an unconfined aquifer, the upper boundary is not fixed. Definition of the upper boundary also reflects input of water from disposal facilities, irrigation, or natural recharge. The lower boundary may be a no-flow boundary or a prescribed flux boundary describing the leakage of water to or from the underlying confined aquifer system.

The areal extent of the model is defined by physical boundaries, including the Columbia River on the east and north, and basalt outcrops and the Yakima River on the west and south. Because development of a three-dimensional conceptual model is a very large task, the work is being done over a period of several years. Work conducted during FY 1992 (Thorne and Chamness 1992) focused on defining the hydrogeologic structure of the unconfined aquifer in the area extending eastward from the 200-East Area to the Columbia River. Most of the contaminants discharged to waste-water disposal facilities in the 200-East Area travel through the unconfined aquifer in this area. During FY 1993, work on the conceptual model concentrated on extending the definition of hydrogeologic layers to the west and south, assigning hydraulic properties to layers within this region, defining the bottom surface of the unconfined aquifer system over the entire site, and collecting data to better define the boundary corresponding to the Yakima River on the southwest edge of the site. This work is documented by Thorne et al. (1993). 


\subsection{Three-Dimensional Ground-Water Model}

As discussed in Chapter 4.0, the previous numerical models developed at the Hanford Site have been two-dimensional. This is an adequate representation for estimating quantities of flow, but is not adequate for predicting contaminant transport. In particular, the vertical distribution of contaminants cannot be accurately simulated and predicted with a two-dimensional model. Furthermore, a three-dimensional model will allow simulation of vertical hydraulic gradients.

\subsection{Modeling Approach}

A three-dimensional, multilayer ground-water model is being developed based on the threedimensional geohydrologic conceptual model described by Thorne et al. (1993). The transmissivity distribution and boundary conditions are taken from the current two-dimensional ground-water model described in Chapter 4.0. Future work will include re-evaluating the boundary conditions of the model (in particular, the water-table and river elevations), surface recharge, and, potentially, discharges from the underlying basalt formation to the unconfined aquifer unit. As discharges to ponds and cribs at the Hanford Site are reduced, the recharge to the unconfined aquifer unit from precipitation and the underlying basalts may be more important and could have a significant effect on water-table elevations. Also, the geohydrologic conceptual model will be refined as more geologic information becomes available, providing for additional refinements to the three-dimensional ground-water model.

\subsection{Single-layer Flow Model}

As a first step toward developing a three-dimensional, multilayer ground-water model, the current two-dimensional model (Chapter 4.0) was converted to a three-dimensional, single-layer flow model using the underlying basalt formation (described in Chapter 5.0) as the base of the model.

The December 1979 water-table elevation (Figure 4.9) and the most current top-of-basalt surface (Figure 6.1) were used to define the single-layer unconfined aquifer unit of the new threedimensional model. Significant differences existed between the current top-of-basalt surface and 
the base of the two-dimensional model (Figure 6.2), which corresponded to either the top-of-basalt or other impermeable strata (e.g., lower Ringold unit).

Hydraulic conductivities for the three-dimensional model were derived from the transmissivity distribution of the two-dimensional model by dividing the transmissivity value by the saturated thickness of the unconfined unit. Thus, the transmissivity distribution was not modified in the three-dimensional, single-layer model.

All boundary conditions from the two-dimensional model were retained in the threedimensional, single-layer model, including flux and held-head boundary conditions based on steady-state flow conditions representing December 1979. The boundary conditions were set at surface nodes of the finite-element grid.

Steady-state flow simulations (based on 1979 discharge conditions) showed good agreement between the predicted water tables of the two-dimensional model (Figure 6.3) and the three-dimensional, single-layer model (Figure 6.4). Contour maps of the predicted head at the topof-basalt (Figure 6.5), representing the base of the model, were essentially identical to the predicted results at the water table. Travel path analyses (Figures 6.3 and 6.4) also showed good agreement between the two- and three-dimensional results, with the only difference being that several travel paths terminated upon encountering a boundary at the top or base of the model. 


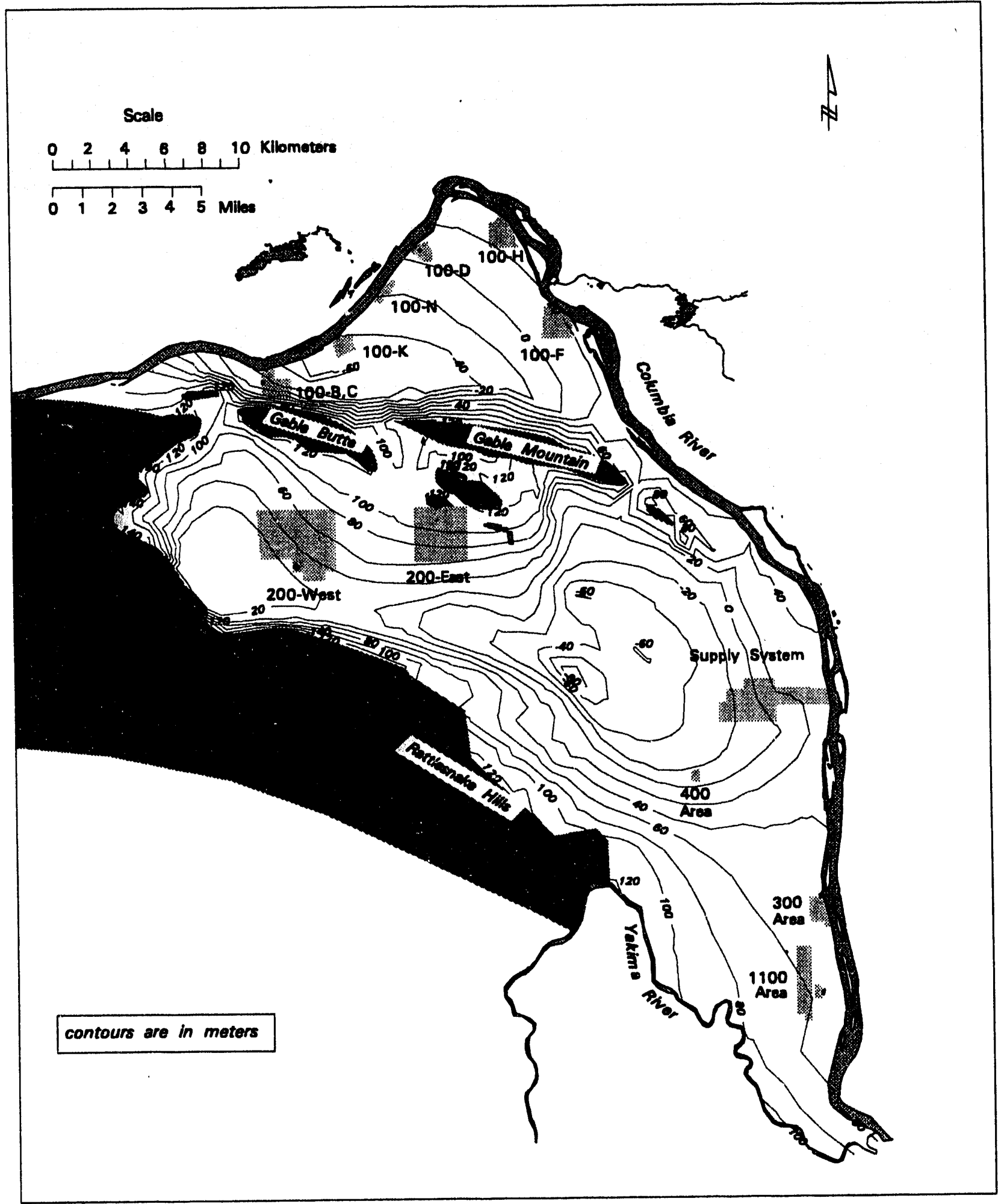

Figure 6.1. Current Top-of-Basalt Contour Map 


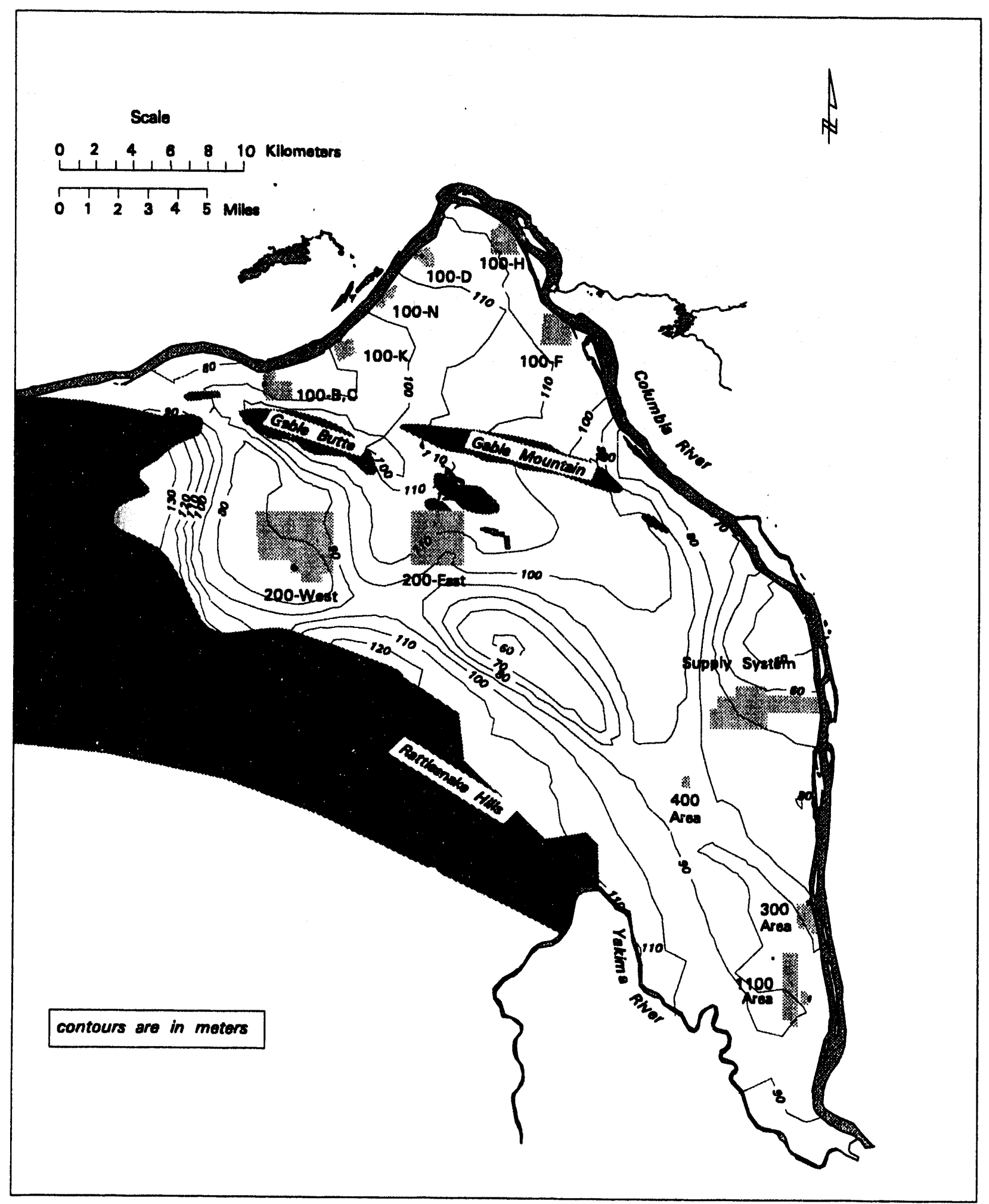

Figure 6.2. Base of the Unconfined Aquifer as Defined by the Two-Dimensional Model 


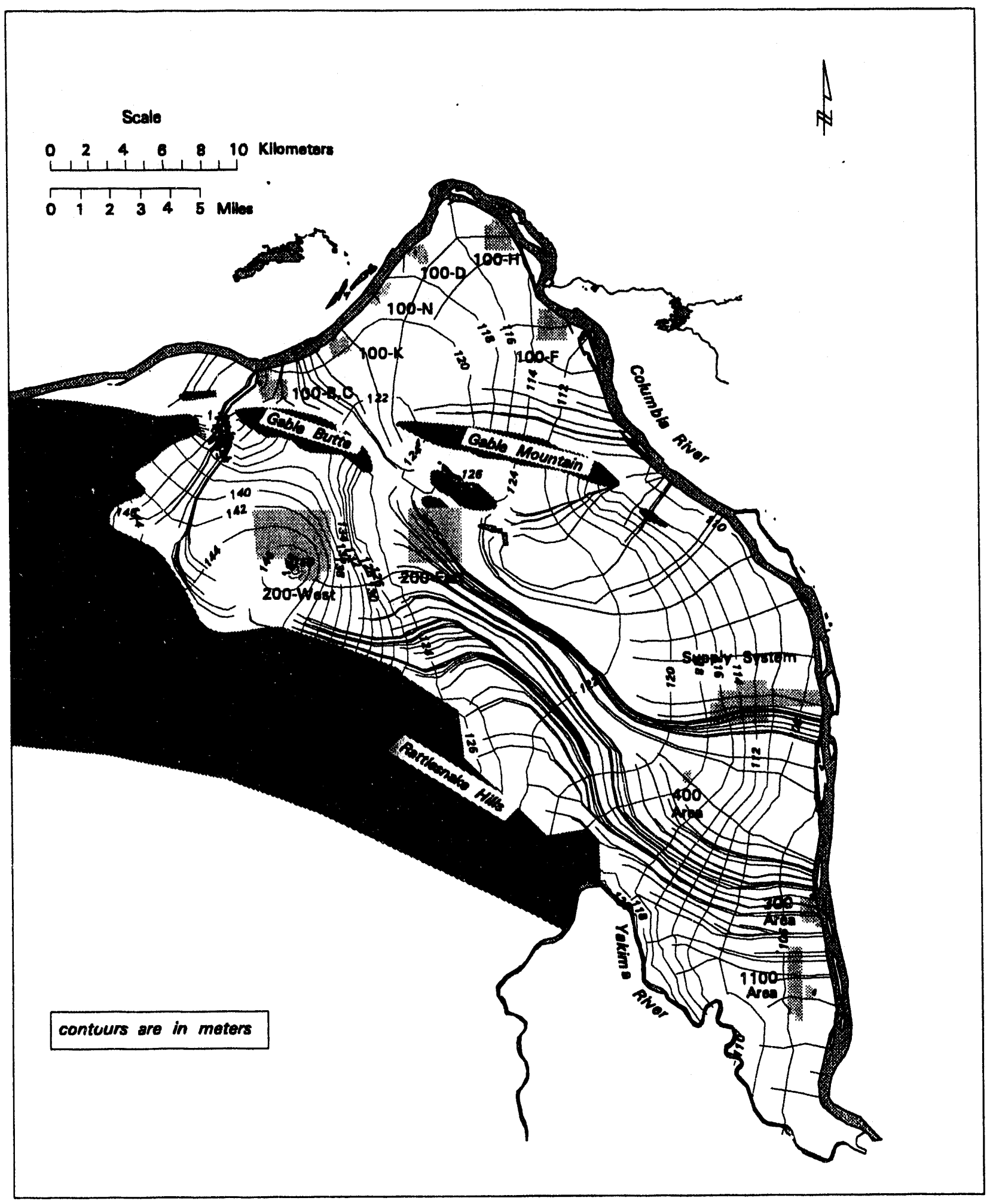

Figure 6.3. Results of Steady-State Simulations for the Two-Dimensional Model (December 1979) 


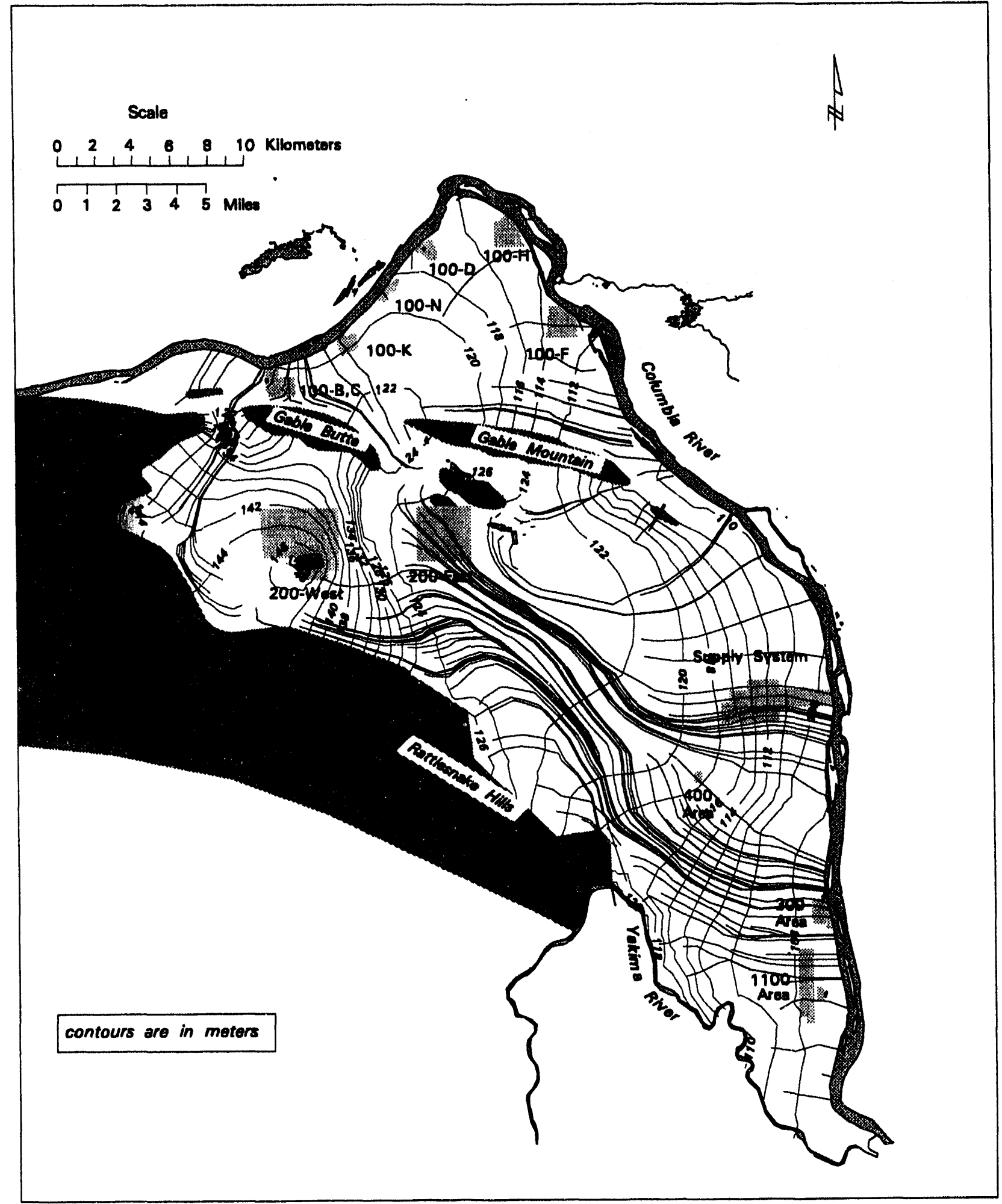

Figure 6.4. Results of Steady-State Simulations for the Three-Dimensional Model (December 1979) 


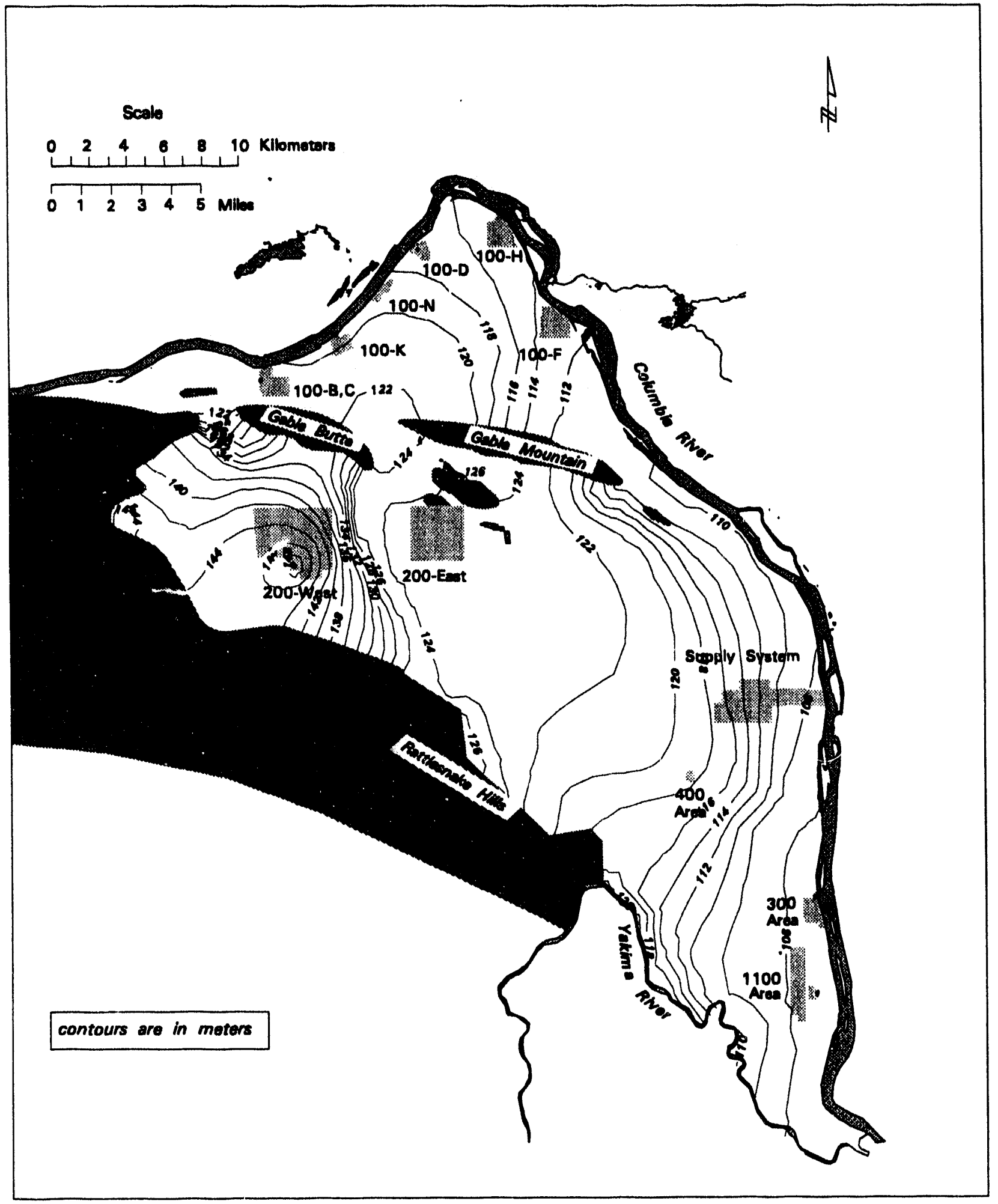

Figure 6.5. Hydraulic Head Contours at the Base of the Aquifer for the Three-Dimensional Model 


\subsection{References}

Ahlstrom, S. W., H. P. Foote, R. C. Amett, C. R. Cole, and R. J. Seme. 1977. Multicomponent Mass Transport Model: Theory and Numerical Implementation (Discrete-Parcel Random-Walk Version). BNWL-2127, Pacific Northwest Laboratory, Richland, Washington.

Bauer, H. H., and J. J. Vaccaro. 1990. Estimates of Ground-Water Recharge to the Columbia Plateau Regional Aquifer System, Washington, Oregon, and Idaho for Predevelopment and Current Land Use Conditions. Water Resources Investigation Report 88-4108, U.S. Geological Survey, Tacoma, Washington.

Brown, M. J., R. K. P'Pool, and S. P. Thomas. 1990. Westinghouse Hanford Company Effluent Discharges and Solid Waste Management Report for Calendar Year 1989: 200/600 Areas. WHC-EP-0141-2, Westinghouse Hanford Company, Richland, Washington.

Cearlock, D. B., K. L. Kipp, and D. R. Friedrichs. 1975. The Transmissivity Iterative Calculation Routine - Theory and Numerical Implementation. BNWL-1706, Pacific Northwest Laboratory, Richland, Washington.

Cole, C. R., S. B. Yabusaki, and C. T. Kincaid. 1988. CFEST-SC: Coupled Fluid, Energy, and Solute Transport Code, SuperComputer Version, Documentation and User's Manual. Battelle Pacific Northwest Laboratories, Richland, Washington.

DOE. 1987. Final Environmental Impact Statement, Disposal of Hanford Defense High-Level, Transuranic and Tank Waste, Hanford Site, Richland, Washington. DOE/EIS-0113, Vol. 1-5, U.S. Department of Energy, Richland, Washington.

DOE. 1988. Consultation Draft, Site Characterization Plan, Reference Repository Location, Hanford Site, Washington. DOE/RW-0164, Vol. 1 and 2, U.S. Department of Energy, Richland, Washington. 
Evans, J. C., D. I. Dennison, R. W. Bryce, P. J. Mitchell, D. R. Sherwood, K. M. Krupka, N. W. Hinman, E. A. Jacobson, and M. D. Freshley. 1988. Hanford Site Ground-Water Monitoring for July Through December 1987. PNL-6315-2, Pacific Northwest Laboratory, Richland, Washington.

Freshley, M. D., and M. J. Graham. 1988. Estimation of Ground-Water Travel Time at the Hanford Site: Description, Past Work, and Future Needs. PNL-6328, Pacific Northwest Laboratory, Richland, Washington.

Freshley, M. D., and P. D. Thome. 1992. Ground-Water Contribution to Dose from Past Hanford Operations. PNWD-1974HEDR, Pacific Northwest Laboratory, Richland, Washington.

Friedrichs, D. R., C. R. Cole, and R. C. Amett. 1977. Hanford Pathline Calculational Program Theory, Error Analysis and Applications. ARH-ST-149, Atlantic Richfield Hanford Company, Richland, Washington.

Gee, G. W., and P. R. Heller. 1985. Unsaturated Water Flow at the Hanford Site: A Review of Literature and Annotated Bibliography. PNL-5428, Pacific Northwest Laboratory, Richland, Washington.

Graham, M. J., G. V. Last, and K. R. Fecht. 1984. An Assessment of Aquifer Intercommunication in the B Pond, Gable Mountain Pond Area. RHO-RE-ST-12P, Rockwell Hanford Operations, Richland, Washington.

Gupta, S. K., C. R. Cole, C. T Kincaid, and A. M. Monti. 1987. Coupled Fluid, Energy, and Solute Transport (CFEST) Model: Formulation and User's Manual. Report BMI/ONWI-660, Battelle Memorial Institute, Columbus, Ohio.

Jacobson, E. A. 1985. A Statistical Parameter Estimation Method Using Singular Value Decomposition with Application to Avra Valley Aquifer in Southern Arizona. Dissertation, Department of Hydrology and Water Resources, University of Arizona, Tucson, Arizona. 
Jaoobson, E. A., and M. D. Freshley. 1990. An Initial Inverse Calibration of the Ground-Water Flow Model for the Hanford Unconfined Aquifer. PNL-7144, Pacific Northwest Laboratory, Richland, Washington.

Kipp, K. L., A. E. Reisenauer, C. R. Cole, and L. A. Bryan. 1972. Variable Thickness Transient Groundwater Flow Model: Theory and Numerical Implementation. BNWL-1703, Pacific Northwest Laboratory, Richland, Washington.

Neuman, S. P. 1980. "A Statistical Approach to the Inverse Problem of Aquifer Hydrology: 3. Improved Solution Method and Added Perspective." Water Resources Research, 16(2):331-346.

Newcomb, R. C., J. R. Strand, and F. J. Frank. 1972. Geology and Ground-Water Characteristics of the Hanford Reservation of the U.S. Atomic Energy Commission, Washington. Prof. Paper 717, U. S. Geological Survey, Washington, D.C.

Simmons, C. S., C. T. Kincaid, and A. E. Reisenauer. 1986. A Simplified Model for Radioactive Contaminant Transport: The TRANSS Code. PNL-6029, Pacific Northwest Laboratory, Richland, Washington.

Spane, F. A., Jr. 1987. Fresh-Water Potentiometric Map and Inferred Flow Direction of Ground Water Within the Mabton Interbed, Hanford Site, Washington State - January 1987. SD-BWI-TI335, Rockwell Hanford Operations, Richland, Washington.

Thome, P. D., and M. A. Chamness. 1992. Status Report on the Development of a ThreeDimensional Conceptual Model for the Hanford Site Unconfined Aquifer System. PNL-8332, Pacific Northwest Laboratory, Richland, Washington.

Thorne, P. D., M. A. Chamness, F. A. Spane, V. R. Vermeul, and W. D. Webber. 1993. Three-Dimensional Conceptual Model for the Hanford Site Unconfined Aquifer System, FY93 Status Report . PNL-8971, Pacific Northwest Laboratory, Richland, Washington. 


\section{Appendix A}

\section{CFES T Input File Describing Finite-Element Grid Information and Materiai Properties for the Two-Dimensional Hanford Regional Flow Model}

Note: Because of the size, this is included on an IBM formatted disk in WordPerfect 5.1 and as an ASCII file. 


\section{Appendix B}

CFEST Input File Describing Flux and Time Step Information for the Two-Dimensional Hanford Regional Flow Model

Note: Because of the size, this is included on an IBM formatted disk in WordPerfect 5.1 and as an ASCII file. 


\section{Appendix C}

Plates Showing Node and Element Numbering Schemes for the CFEST Input Files Used in the Two-Dimensional Hanford Regional Flow Model 


\section{Distribution}

No. of

Copies

\section{OFFSITE}

12 DOE/Office of Scientific and Technical Information

B. Blake

133 1st Avenue North

Minneapolis, MN 55401

\section{A. Danielson}

Washington State Department of

Health

1801 South 66th Ave.

Yakima, WA 98808

T. Gilmore

Confederated Tribes of the Umatilla

Indian Reservation

Department of Natural Resources

Hanford Projects

P.O. Box 638

Pendleton, OR 97801

3 D. Nilander

Washington State Department of Ecology

7601 W. Clearwater Avenue

Suite 102

Kennewick, WA 99336

R. Patt

Oregon State Department of

Water Resources

3850 Portland Road

Salem, OR 97310

$2 \quad$ U.S. Geological Survey

1201 Pacific Ave Suite 600

Tacoma, WA 98402

B. Drost

W. Lumm
No. of

Copies

3 Washington State Department of Ecology

99 South Sound Center

M.S. 7600

Olympia, WA $98504-7600$

C. Cline

D. Jansen

K. Kowalic

2 Washington State Department of Health

Division of Radiation Protection

Airdustrial Center

Building 5, M.S. L-13

Olympia, WA 98503
J. Erickson

G. Robertson

\section{ONSITE}

21 DOE Richland Operations Office

G. M. Bell

J. K. Erickson

M. J. Furman

E. D. Goller

J. D. Goodenough

A. C. Harris

R. D. Hildebrand (10)

R. G. Holt

R. G. McLeod

P. M. Pak

R. K. Stewart

K. M. Thompson
A5-52

A5- 19

R3-80

A5-19

A5-19

A5-19

A5-55

A5-15

A5-19

A5-19

A5-19

A5-15

Distr.1 
No. of

Copies

2 U.S.Army Corps of Engineers

W. Greenwald

A5-20

M. P. Johansen

A5-19

3 U.S. Environmental Protection

Agency

P. T. Day

B5-01

D. R. Sherwood

(2)

B5-01

22 Westinghouse Hanford Company

M. R. Adams

S. W. Clark

L. B. Collard

M. P. Connelly

K. R. Fecht

L. C. Hulstrom

R. L. Jackson

A. J. Knepp

N. K. Lane

M. J. Lauterbach

A. G. Law

K.A. Lindsey

S. M. McKinney

W. J. McMahon

R. E. Peterson

S. P. Reidel

J. W. Roberts

J. A. Serkowski

K. R. Simpson

L. C. Swanson

S. J. Trent

S. E. Vukelich

H6-01

H6-01

H6-01

H6-06

H6-06

H6-03

H6-06

H6-06

H6-01

H6-01

H6-06

H6-06

T1-30

H6-06

H6-06

H6-06

H6-02

H6-06

H6-06

H6-06

H6-06

H6-02

55 Pacific Northwest Laboratory

M. P. Bergeron

B. N. Bjomstad

J. V. Borghese

R. W. Bryce

M. A. Chamness

C. R. Cole

J. L. Devary

P. E. Dresel

C. E. Elderkin
M. D. Freshley

G.W. Gee

R. E. Gephart

T. J. Gilmore

S. H. Hall

M. S. Hanson

R. E. Jaquish

W. W. Laity

G. I'. Last

T. L. Liikala

P. E. Long

S. P. Luttrell

J. P. McDonald

P. D. Meyer

D. R. Newcomer

K. B. Olsen

J. T. Rieger

M. L. Rockhold

R. Schalla

F. A. Spane, Jr.

S. S. Teel

P. D. Thorne (5)

V. R. Vermeul

W. D. Webber

S. K. Wurstner (10)

Publishing Coordination

Technical Report Files (5)

Public Reading Room

\section{Routing}

R. M. Ecker

M. J. Graham

P. M. Irving

C. S. Sloane

P. C. Hays (last)
SE-UI

K6-78

K6-77

K6-77

$\mathrm{K} 1-22$

K6-96

K6-96

K $1-51$

K1-30

K2-50

K6-96

K6-96

K6-84

K6-96

K6-96

K6-77

K6-96

K6-81

K6-96

K6-77

K6-96

K6-96

K6-96

K6-96

K6-96

K6-96

K6-77

K1-06

K6-98

K6-04

K6-86
K6-77

K6-96

K6-96

K6-96

K6-96

K6-77

K6-77

K6-81

K6-11

Distr.2 


\section{Plate 1. Numbering}

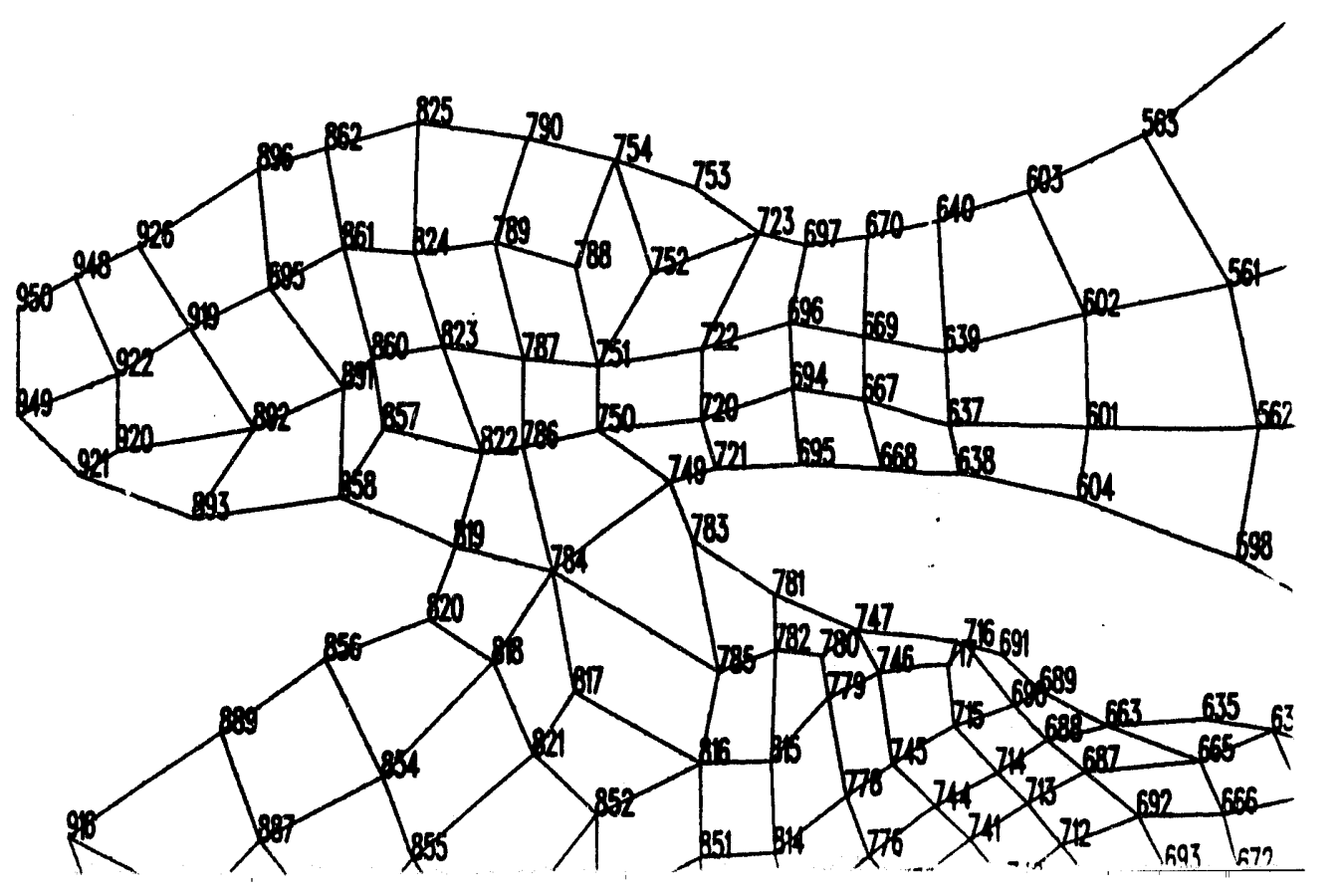




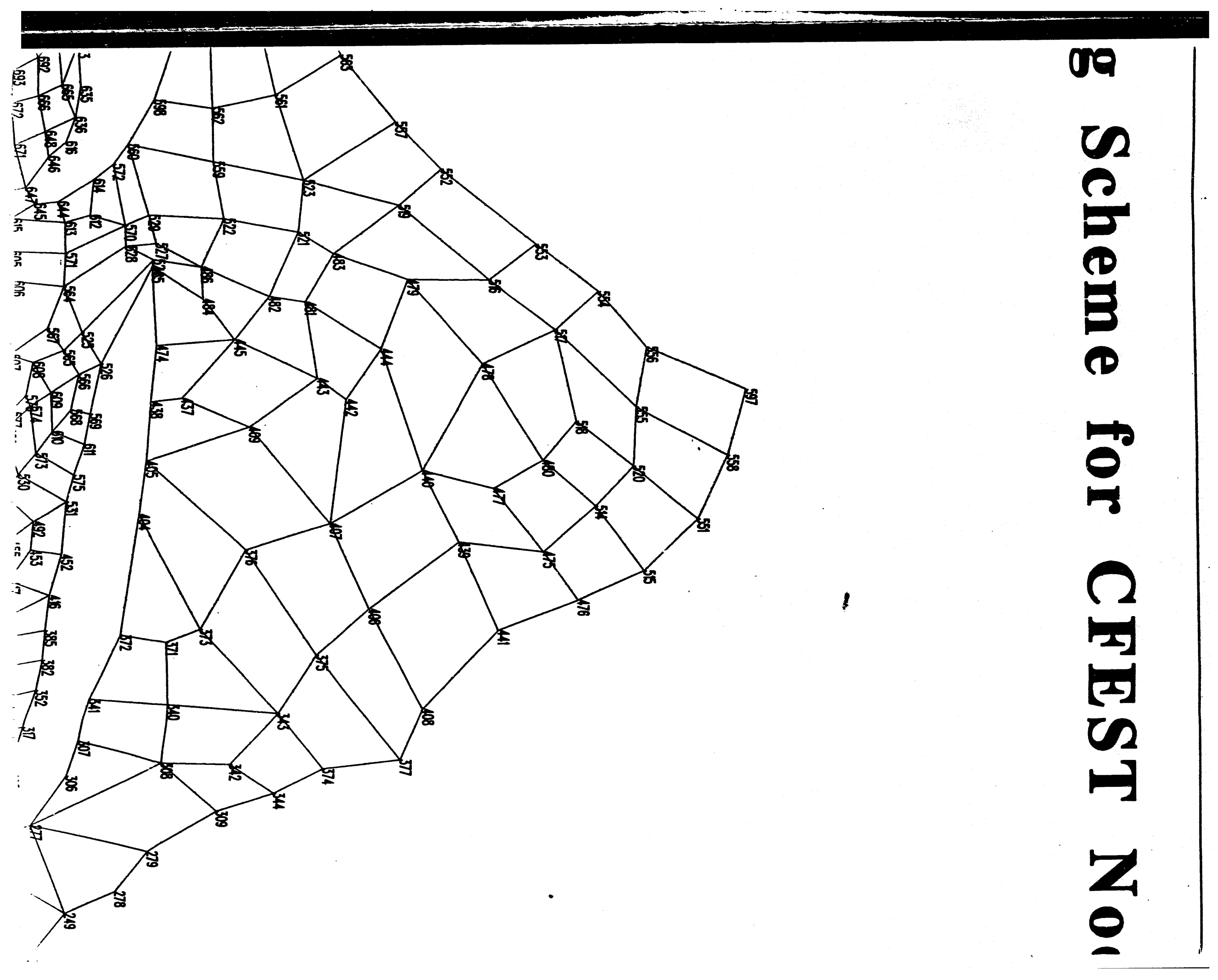




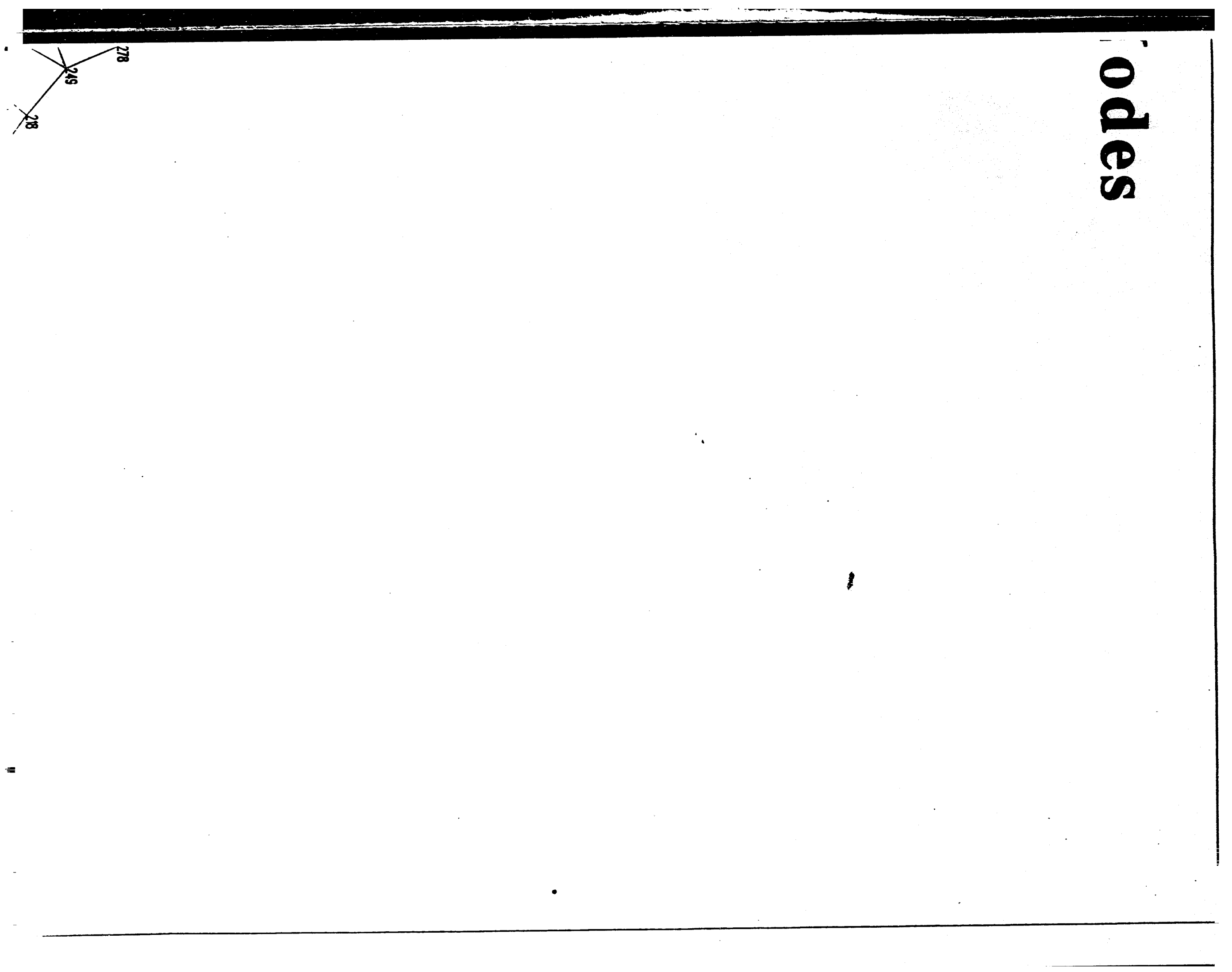




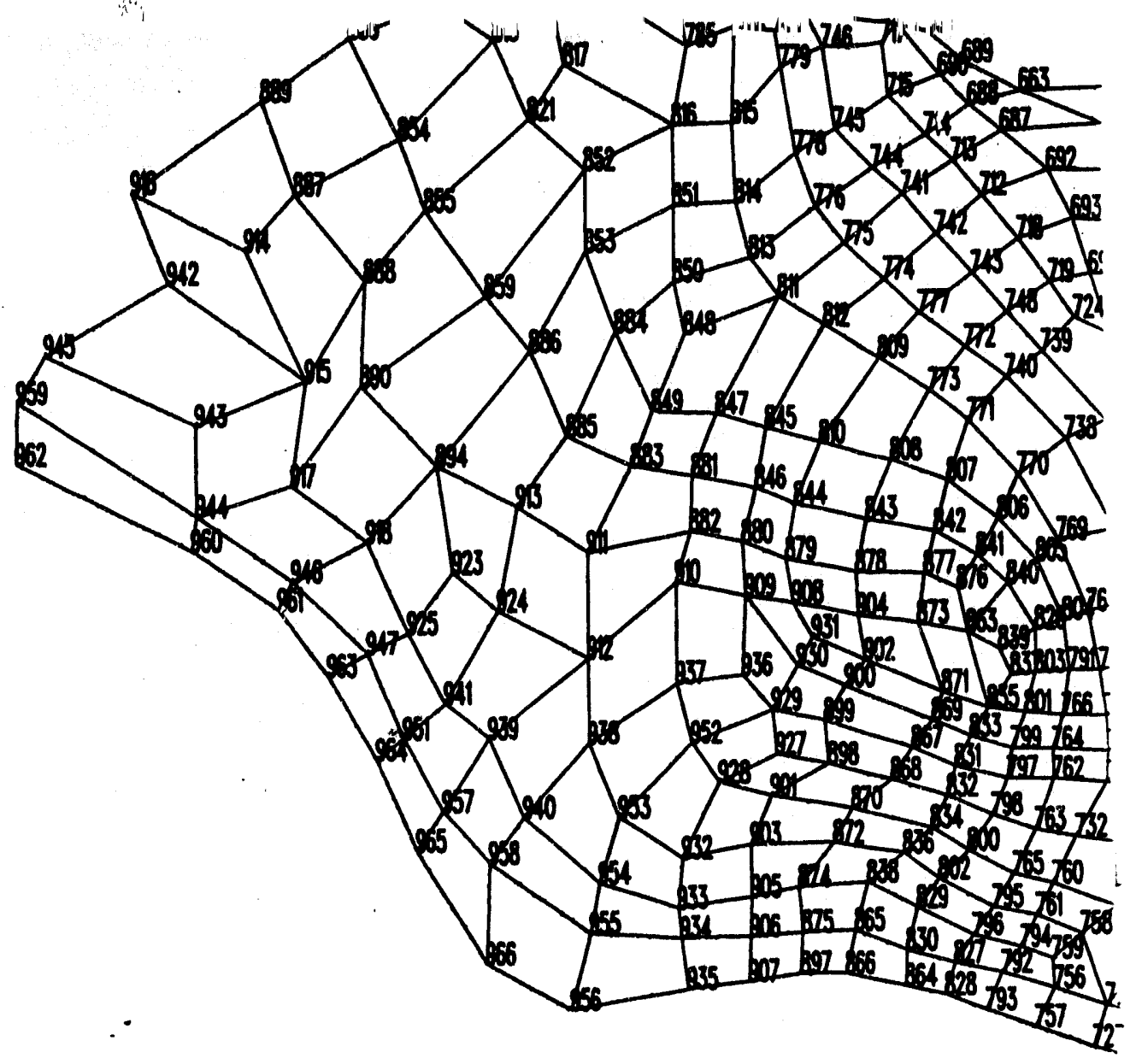




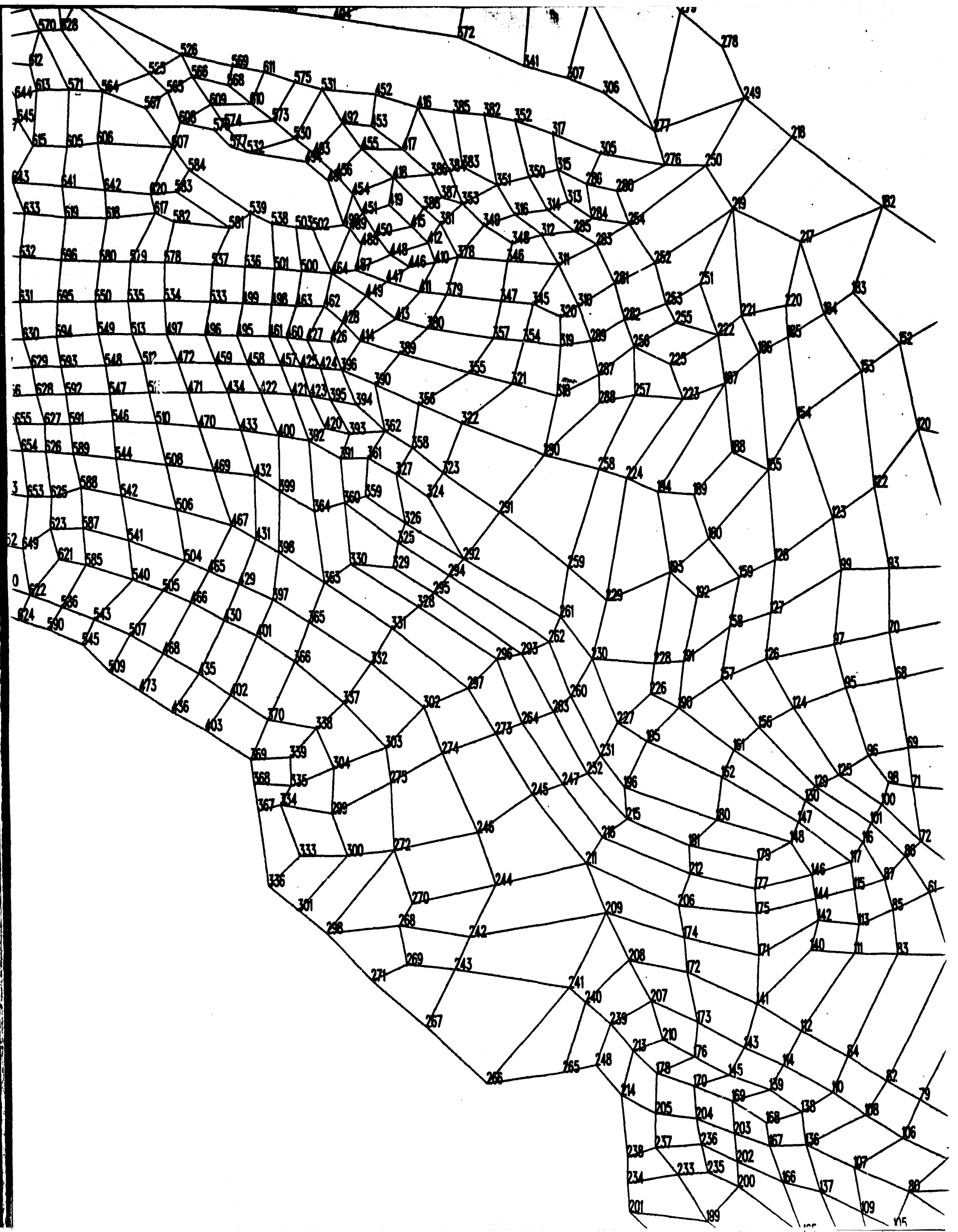




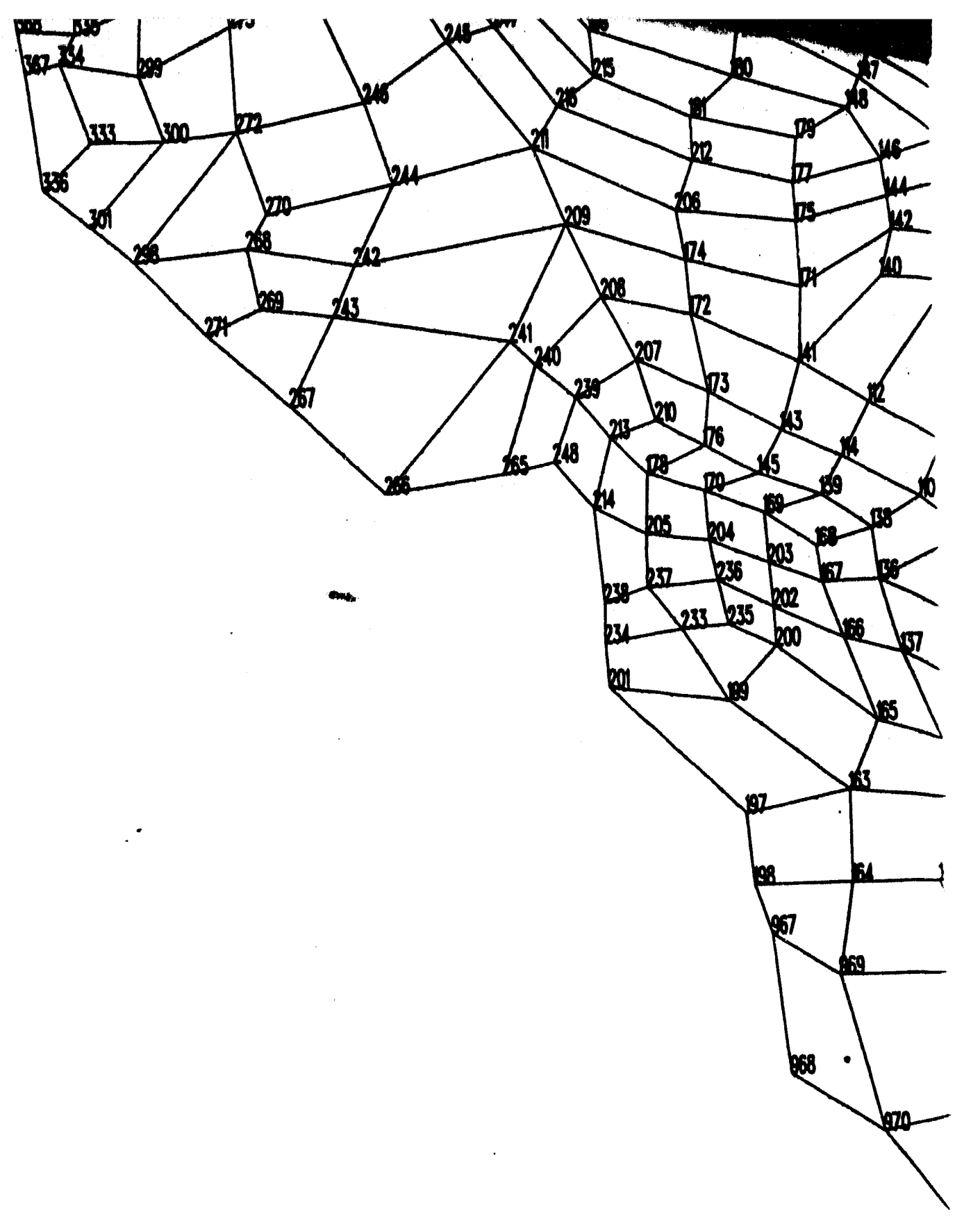




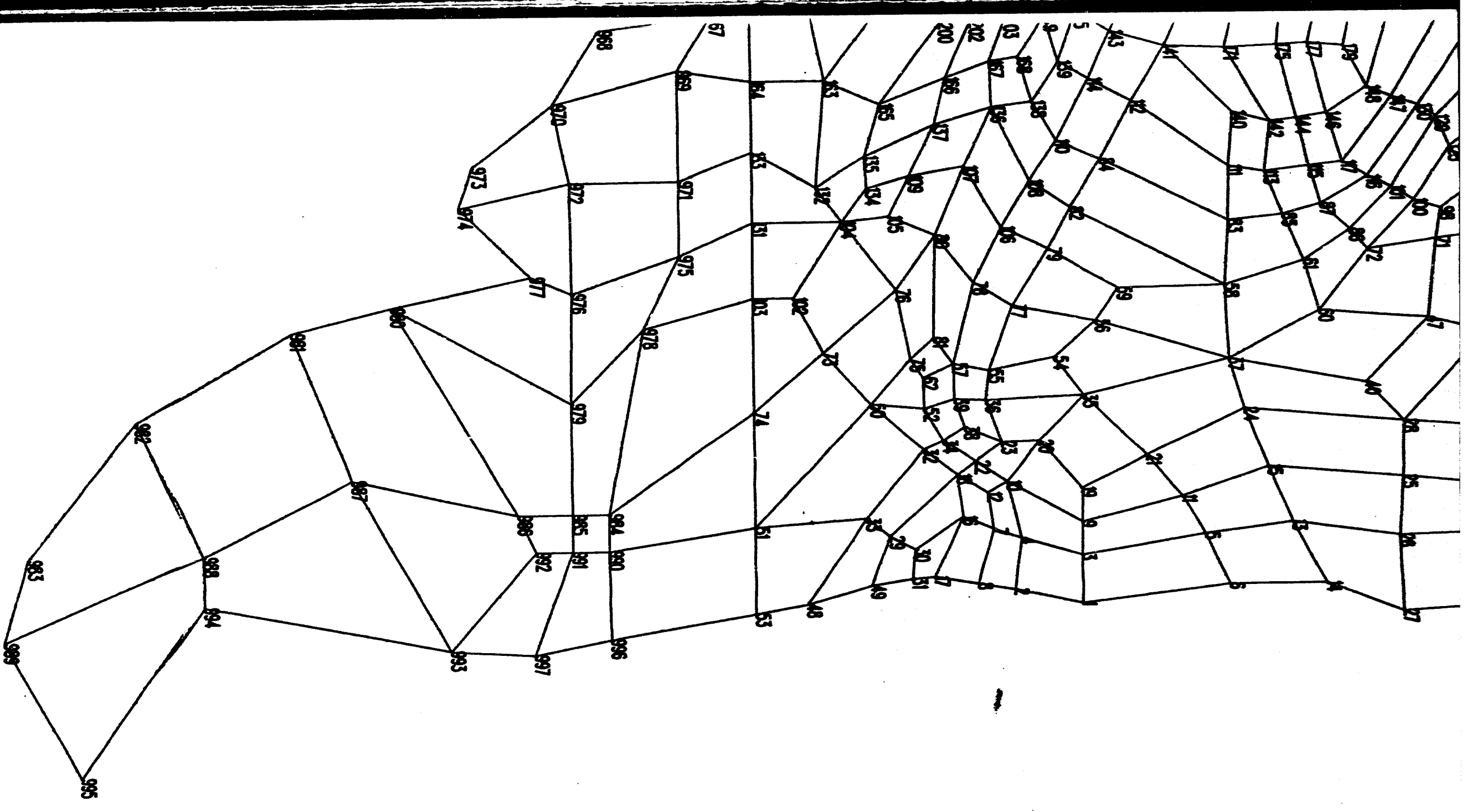




\section{Plate 2. Numbering}

$-$

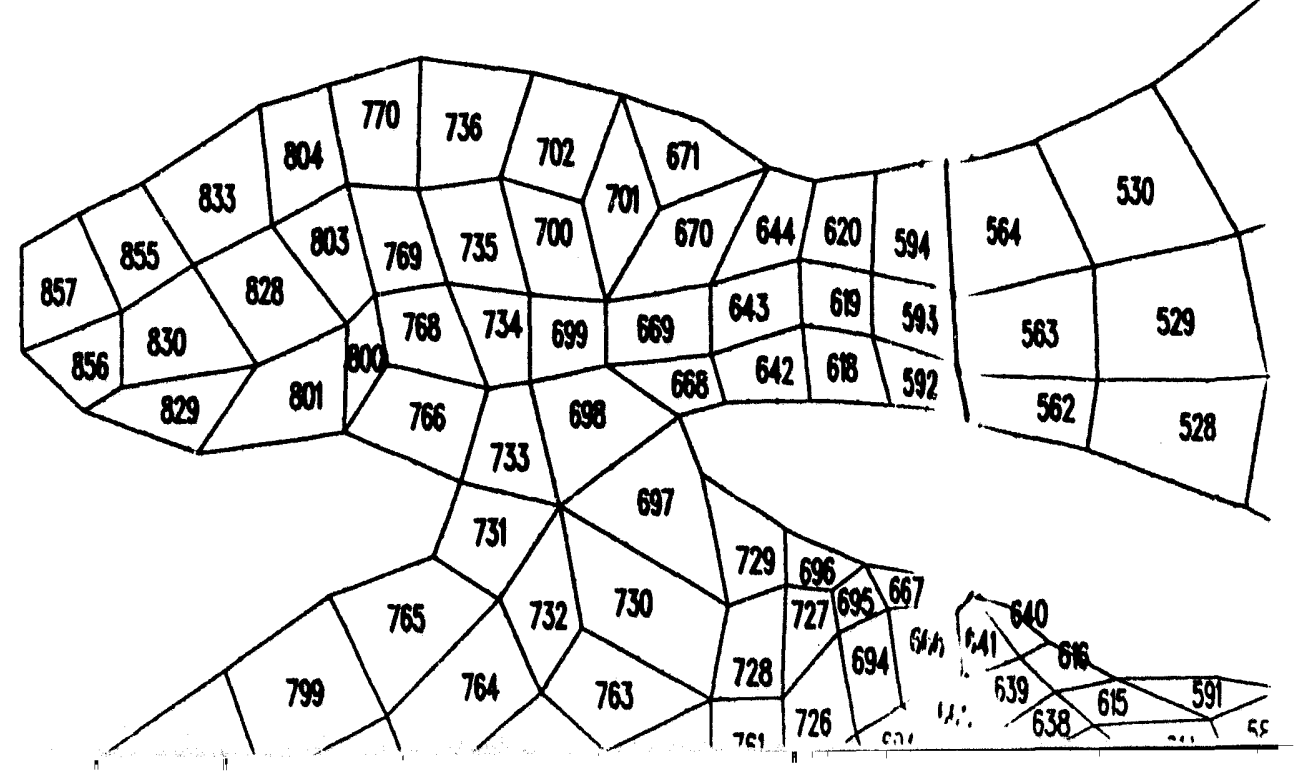




\section{Scheme for CFEST Elemı}

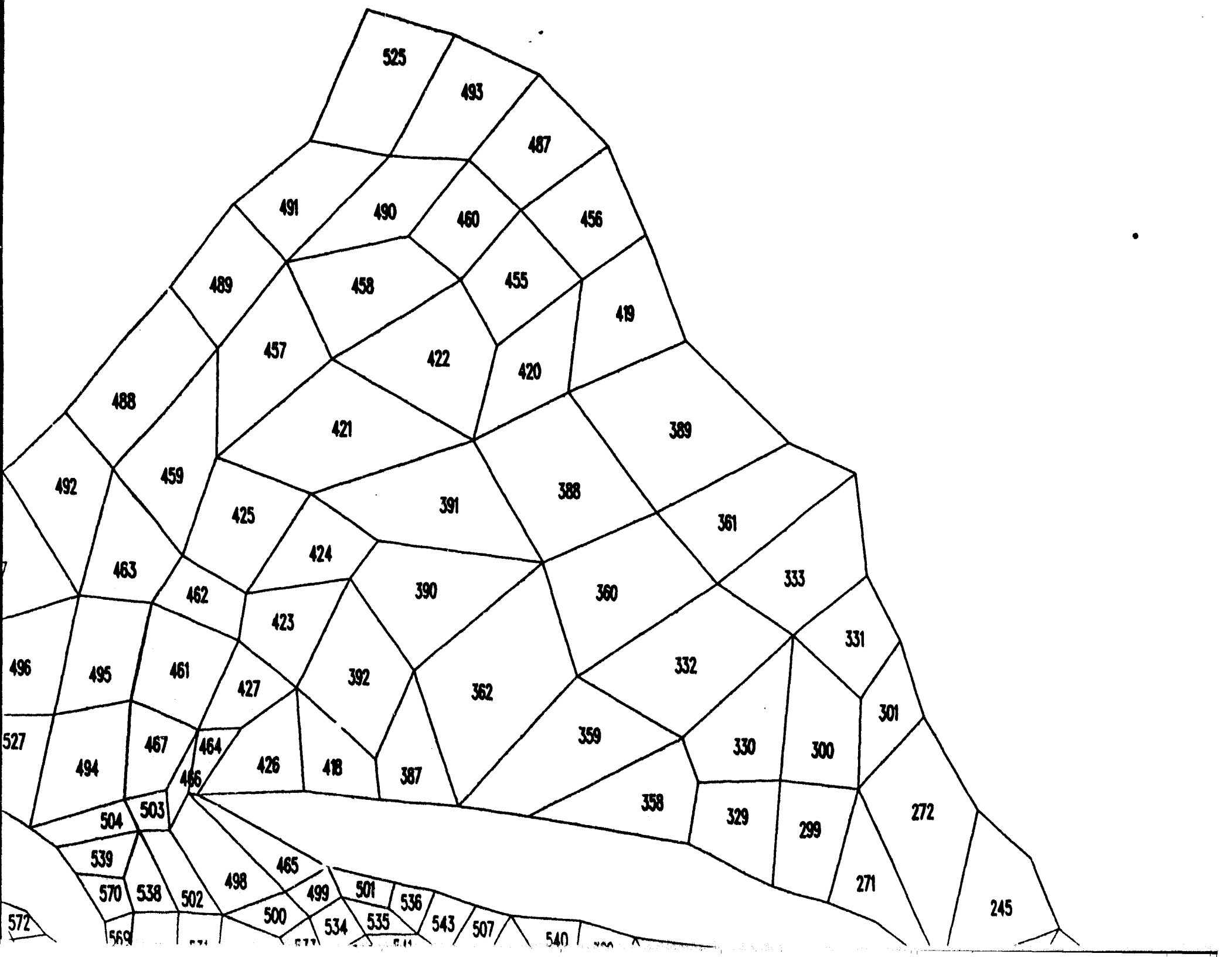




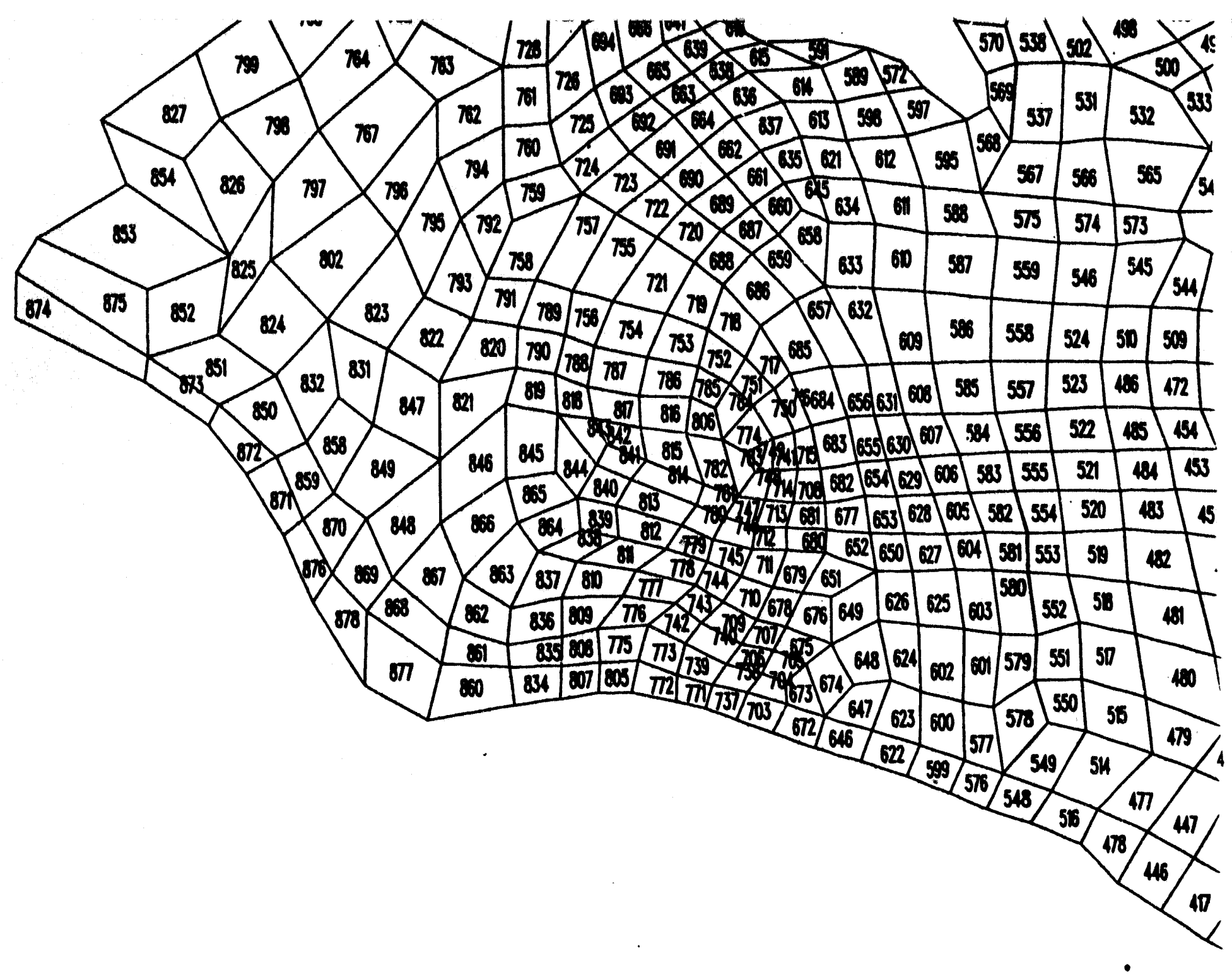




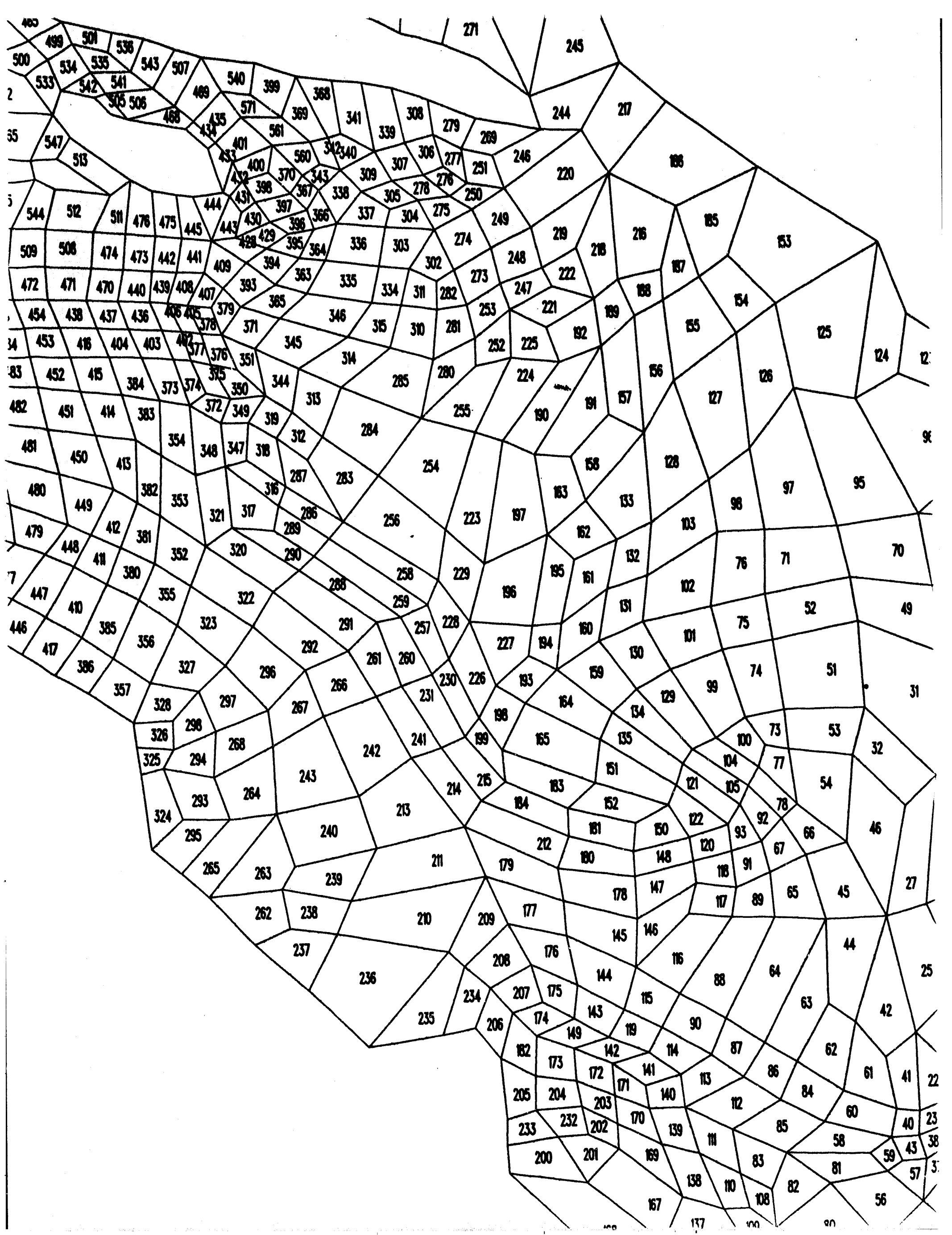




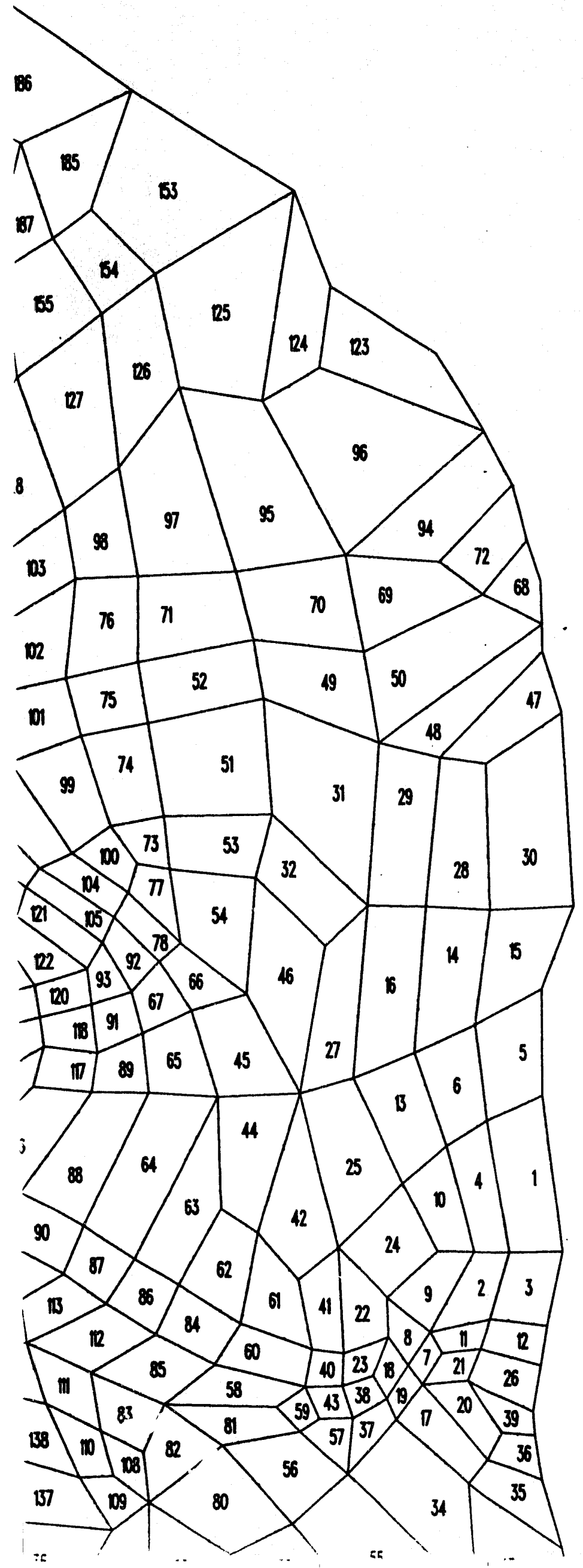




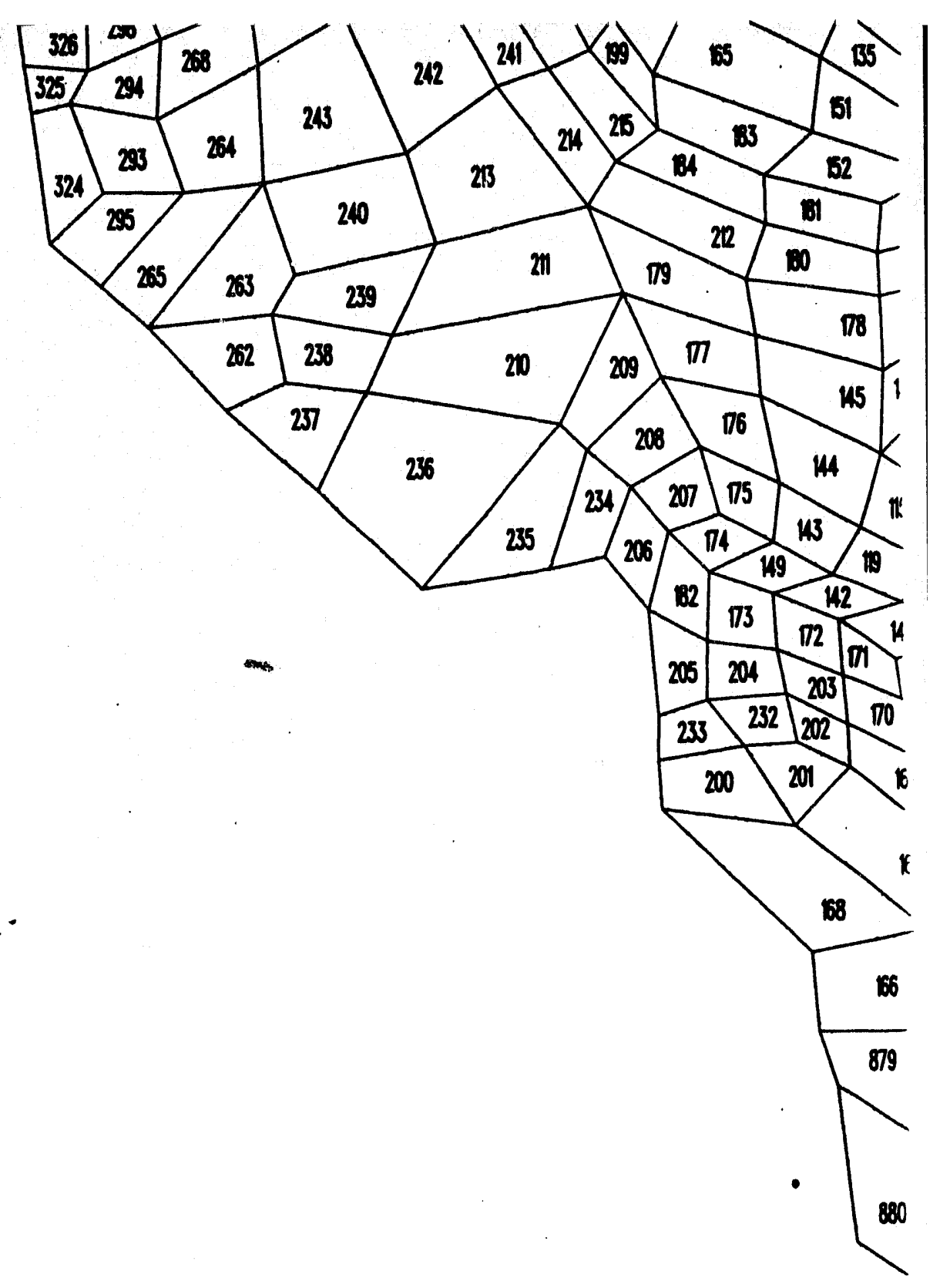




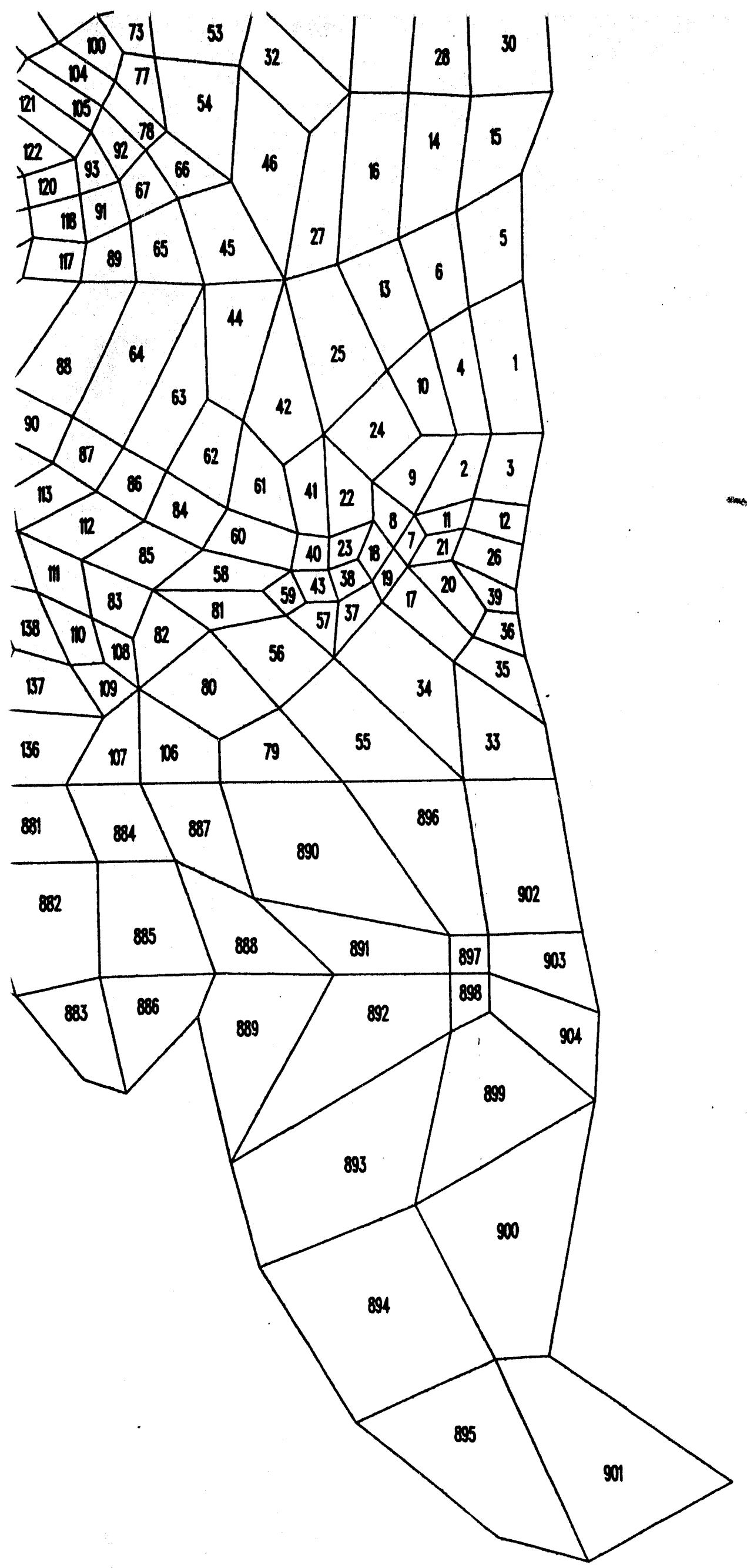




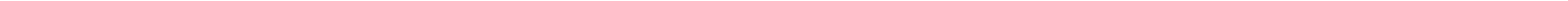


